\title{
Hydrogen Peroxide Stimulates the Synthesis of Platelet-activating Factor by Endothelium and Induces Endothelial Cell-dependent Neutrophil Adhesion
}

\author{
Michael S. Lewis, Ralph E. Whatley, Patricia Cain, Thomas M. Mclntyre, Stephen M. Prescott, and Guy A. Zimmerman \\ Nora Eccles Harrison Cardiovascular Research and Training Institute, and Departments of Internal Medicine and Biochemistry, \\ University of Utah School of Medicine, Salt Lake City, Utah 84112
}

\begin{abstract}
Oxidant-induced damage to the intima of pulmonary and systemic vessels is thought to be an important mechanism of injury in a variety of syndromes of vascular damage. Hydrogen peroxide $\left(\mathrm{H}_{2} \mathrm{O}_{2}\right)$ is an active oxygen metabolite that may induce intimal injury by cytolytic attack or by inducing biochemical and functional alterations in the endothelial cells (EC); however, mechanisms involved in noncytolytic perturbation of EC are largely unknown. We found that $\mathrm{H}_{2} \mathrm{O}_{2}$ stimulated the synthesis of platelet-activating factor (PAF) by primary cultures of bovine pulmonary artery endothelium (BPAEC) and by human umbilical vein endothelium (HUVEC). In each cell type the incorporation of $\left[{ }^{3} \mathrm{H}\right]$ acetate into $\left[{ }^{3} \mathrm{H}\right.$-acetyl]PAF was concentration- and time-dependent and was temporally dissociated from severe plasma membrane disruption and cytolytic cell injury; the newly synthesized PAF remained associated with the EC. $\mathrm{H}_{2} \mathrm{O}_{2}$ caused permeabilization of $\mathrm{EC}$ to ${ }^{45} \mathrm{Ca}^{2+}$ and an increase in intracellular $\mathrm{Ca}^{2+}$, suggesting that a transmembrane $\mathrm{Ca}^{2+}$ flux is the signal that initiates PAF synthesis. $\mathrm{H}_{2} \mathrm{O}_{2}$ also induced the endothelial cell-dependent adhesion of neutrophils to HUVEC monolayers. This response was rapid, with an onset within minutes and a subsequent time course that paralleled the time course of PAF accumulation, and was dependent on extracellular $\mathrm{Ca}^{2+}$ but not on de novo protein synthesis. These studies demonstrate that $\mathrm{H}_{2} \mathrm{O}_{2}$ can induce two rapid activation responses of endothelium, PAF synthesis and EC-dependent neutrophil adhesion, events that may be important in physiologic and pathologic inflammation.
\end{abstract}

\section{Introduction}

It is currently thought that oxidant-induced injury to endothelium is an important mechanism of vascular damage (1-3). Injury to the vascular intima caused by oxidants can result from endogenously produced active $\mathrm{O}_{2}$ metabolites that are generated in response to high partial pressures of $\mathrm{O}_{2}$, ionizing radiation, or drugs, or by oxidant species released by other cells, such as leukocytes (1-12). Hydrogen peroxide $\left(\mathrm{H}_{2} \mathrm{O}_{2}\right)$, in

Parts of this work were presented at the annual meeting of the Western Section of the American Federation for Clinical Research, Carmel, CA, 6 February 1987, and at the national meeting of the Federation, San Diego, CA, 2 May 1987, and have appeared in abstract form (1987. Clin. Res. 5:171A; 1987. Clin. Res. 35:535A).

Address reprint requests to Dr. Zimmerman.

Received for publication 4 December 1987 and in revised form 19 July 1988

J. Clin. Invest.

(C) The American Society for Clinical Investigation, Inc.

$0021-9738 / 88 / 12 / 2045 / 11 \quad \$ 2.00$

Volume 82, December 1988, 2045-2055 particular, may be a key molecular species in such injury: it has been implicated in in vitro endothelial cell (EC) ${ }^{1}$ injury (4-13), increased vascular permeability in ex vivo and wholeanimal lung models (14-17), and in postischemic tissue reperfusion injury (18). One mechanism of this injury is lysis of EC (4-11). However, it is also possible that $\mathrm{H}_{2} \mathrm{O}_{2}$ causes changes in the endothelium that initiate or amplify vascular responses in the absence of, or before, cytolytic injury, such as the synthesis of biologically active molecules.

EC synthesize a number of substances that may be involved in local mechanisms of coagulation and inflammation (19). One of these is platelet-activating factor (1-0-alkyl-2-acetyl-sn-glycero-3-phosphocholine; PAF) $(20,21)$, which is produced when EC are stimulated by agonists that interact with specific plasma membrane receptors $(22,23)$. PAF is a phospholipid autacoid with known vasoactive and proinflammatory effects (24-26). Although it may be important in local vascular homeostasis $(20,26)$, it has also been implicated as a mediator of vascular injury (20, 27-32). For example, it causes pulmonary hypertension and lung edema under some conditions (29-32). Since $\mathrm{H}_{2} \mathrm{O}_{2}$ also causes these vascular responses (14-17), we examined the possibility that PAF may be produced by endothelium that has been perturbed by $\mathrm{H}_{2} \mathrm{O}_{2}$. Our findings demonstrate that $\mathrm{H}_{2} \mathrm{O}_{2}$ induces the synthesis and accumulation of PAF by bovine pulmonary artery endothelial cells (BPAEC) and human umbilical vein endothelial cells (HUVEC) in a concentration-, time-, and calcium-dependent manner that is temporally dissociated from lytic cell injury. In addition, $\mathrm{H}_{2} \mathrm{O}_{2}$ stimulates endothelial cell-dependent neutrophil adherence that is tightly coupled with PAF synthesis, suggesting that PAF may mediate the cell-cell interaction.

\section{Methods}

\section{Materials}

PAF ( $>99 \%$ pure) was purchased from Avanti Polar Lipids, Inc. (Birmingham, AL). Calcium ionophore A23187 (IoA), cycloheximide, actinomycin D, bradykinin, catalase, and superoxide dismutase (SOD) were from Sigma Chemical Co. (St. Louis, MO), $\left[{ }^{3} \mathrm{H}\right]$ acetate $(3.4 \mathrm{Ci}$ / mmol) and $\left[{ }^{45} \mathrm{Ca}^{2+}\right]$ chloride from New England Nuclear (Boston, MA), medium 199 and antibiotic solutions from M. A. Bioproducts (Walkersville, MD) or KC Biologicals (Lenexa, KS), hydrogen peroxide (30\% solution) from Mallinckrodt, Inc. (Paris, KY), Hanks' balanced salt solution (HBSS) from M. A. Bioproducts or Life Technologies (Grand Island, NY), Hepes from Behring Diagnostics (La Jolla, CA), fetal bovine serum from Hyclone Laboratories (Logan, UT),

1. Abbreviations used in this paper: BPAEC, bovine pulmonary artery endothelial cell(s); EC, endothelial cell(s); Fn, fibronectin; HUVEC, human umbilical vein endothelial cell(s); IoA, ionophore A23187; PAF, platelet-activating factor; pBPB, para-bromophenacyl bromide; SOD, superoxide dismutase; vWF, von Willebrand factor. 
collagenase from Cooper Biomedical, Inc. (Malvern, PA), precoated plates of silica gel 60 from Merck (Darmstadt, Federal Republic of Germany), and EDTA from Fisher Scientific Co. (Fairlawn, NJ). Purified human thrombin was a gift from Dr. John Fenton (Albany, NY). Polyclonal rabbit antisera to human von Willebrand factor (vWF) and human fibronectin (Fn) were from Calbiochem-Behring Corp. (San Diego, CA) and Cappell (Cooper Biomedical, Malvern, PA), respectively, and were shown to interact with vWF and Fn associated with EC by indirect immunofluorescent staining.

\section{EC culture}

Pulmonary artery. Cultures of tightly confluent bovine pulmonary artery EC were prepared utilizing methods described in detail elsewhere (33).

Human umbilical vein. Primary cultures of tightly confluent HUVEC were prepared as previously described $(20,22)$.

EC cultured by these methods were characterized using morphologic (phase-contrast microscopy), immunologic (staining for vWF), and functional (uptake of acetylated LDL, angiotensin-converting enzyme activity, $\mathrm{PGI}_{2}$ synthesis) criteria as previously described $(20,22$, 33). Only primary cultures were used for these experiments.

\section{Assay of PAF production}

Production of PAF in BPAEC was measured by incorporation of $\left[{ }^{3} \mathrm{H}\right]$ acetate into PAF by a modification of the method of Mueller et al. (34) as described in detail elsewhere $(22,33)$. This has been shown to be an accurate method of measuring PAF accumulation in a variety of cell types $(20,22,33-36)$ and to correlate closely with quantitation by gas chromatography-mass spectroscopy $(35)$ or by bioassay $(20,22$, 36). Briefly, the medium was removed from confluent EC monolayers and replaced with $1 \mathrm{ml}$ of HBSS/10 mM Hepes (pH 7.4), containing 25 $\mu \mathrm{Ci}$ of carrier-free $\left[{ }^{3} \mathrm{H}\right]$ acetate, and the appropriate concentration of $\mathrm{H}_{2} \mathrm{O}_{2}$ or control buffer. In some incubations catalase or SOD was included in the incubation mixture. The incubations were performed at $25^{\circ} \mathrm{C}$ and were stopped at the indicated times by the addition of 0.5 $\mathrm{ml}$ of $50 \mathrm{mM}$ acetic acid in methanol. After the addition of the acidified methanol, the cells were scraped from the surface of the culture dish. $50 \mu \mathrm{g}$ of cold "carrier" PAF was added and the lipids were extracted by the method of Bligh and Dyer (37). The sample was dried under $\mathrm{N}_{2}$, dissolved in a known volume of chloroform/methanol $(9: 1)$, and $10 \%$ was removed and used to determine the total radioactivity present. The remaining lipids were then separated by thin layer chromatography on precoated plates of silica gel 60 in $\mathrm{CHCl}_{3} / \mathrm{MeOH} / \mathrm{gla}$ cial acetic acid/water (50:25:8:4). The silica was scraped, in fractions corresponding to authentic standards, from the entire lane of a TLC plate, and the radioactivity in each fraction was determined by liquid scintillation spectrometry. Calculation of the radioactivity incorporated into $\left[{ }^{3} \mathrm{H}\right.$-acetyl]PAF was done as described (33). Identification of the radiolabeled product as PAF in EC incubated in this fashion was established by determining its mobility in TLC and HPLC systems, its pattern of degradation by phospholipases $A_{1}$ and $A_{2}$ and by a highly specific PAF acetylhydrolase isolated from human plasma (38), and by its biologic activity, which was characteristic of PAF (33). The specific activity of $\left[{ }^{3} \mathrm{H}\right.$-acetyl]PAF varies little regardless of the vessel of origin of the EC or the agonist used (33).

The measurement of $\left[{ }^{3} \mathrm{H}\right.$-acetyl $]$ PAF synthesis in HUVEC was performed as described (22), and was similar to the method just outlined for BPAEC.

\section{Measurement of $\mathrm{Ca}^{2+}$ uptake and release by EC}

Assays in divalent cation-free buffer. Incubations of EC with tritiated acetate and $\mathrm{H}_{2} \mathrm{O}_{2}$ were done in nominally $\mathrm{Ca}^{2+}$ and $\mathrm{Mg}^{2+}$-free HBSS with Hepes and $0.1 \%$ EDTA, or in control HBSS with Hepes.

Assay of ${ }^{45} \mathrm{Ca}^{2+}$ flux into endothelial cells. Culture medium was removed from confluent monolayers of EC and the monolayers washed twice with $1 \mathrm{ml}$ of HBSS. The monolayers were then incubated at $25^{\circ} \mathrm{C}$ for the indicated times with $1 \mathrm{ml}$ of $\mathrm{HBSS}\left(\left[\mathrm{Ca}^{2+}\right]=1.3 \mathrm{mM}\right.$, pH 7.4) containing $5 \mu \mathrm{Ci} / \mathrm{ml}$ of ${ }^{45} \mathrm{CaCl}_{2}$ and the indicated concentra- tions of agonist. Control dishes were incubated identically, but without an agonist. At the indicated times, the incubation buffer was removed and the culture dish immersed in three sequential washes of ice-cold HBSS (without calcium) containing $0.1 \%$ EDTA to remove any remaining extracellular ${ }^{45} \mathrm{Ca}^{2+}$. The monolayers were solubilized in $1 \mathrm{ml}$ of $1 \mathrm{M} \mathrm{NH}_{4} \mathrm{OH}$ and placed in scintillation vials for determination of radioactivity.

Assay of ${ }^{45} \mathrm{Ca}^{2+}$ flux from $\mathrm{EC}$. Culture medium was removed from EC monolayers and replaced with $1 \mathrm{ml}$ of medium M199 containing 5 $\mu \mathrm{Ci} / \mathrm{ml}$ of ${ }^{45} \mathrm{CaCl}_{2}$. After $1 \mathrm{~h}$ of incubation at $37^{\circ} \mathrm{C}$, the labeling medium was removed and the monolayers were washed twice with $1 \mathrm{ml}$ of HBSS. The monolayers were stimulated with the indicated agonist concentration in $1 \mathrm{ml}$ of calcium-free HBSS (pH 7.4) at $25^{\circ} \mathrm{C}$. Control incubations were performed identically, but without an agonist. At the indicated times, the incubation buffer was removed and the monolayers were washed with $1 \mathrm{ml}$ of HBSS. The monolayers were solubilized in $1 \mathrm{ml}$ of $1 \mathrm{M} \mathrm{NH}_{4} \mathrm{OH}$ and placed in scintillation vials for determination of radioactivity.

\section{Measurements of EC injury and cytotoxicity}

The morphology of EC and detachment of EC from the monolayers was assessed by phase-contrast microscopy. The uptake of trypan blue was measured by a minor modification of the method detailed by Patterson (39). Lactate dehydrogenase (LDH) release was measured as described (36).

\section{Measurement of neutrophil adherence to EC and to cell-free surfaces}

Human neutrophils were isolated, labeled with ${ }^{11}$ indium, and their adherence to HUVEC monolayers was measured as described $(40,41)$. In most experiments EC monolayers were pretreated with $\mathrm{H}_{2} \mathrm{O}_{2}$ (diluted from a $30 \%$ stock solution with $\mathrm{HBSS} / 0.5 \%$ human serum albumin) for various times at $37^{\circ} \mathrm{C}$ in an atmosphere of $5 \% \mathrm{CO}_{2}, 95 \%$ air. In some experiments $\mathrm{HUVEC}$ were pretreated with $\mathrm{H}_{2} \mathrm{O}_{2}$ in $\mathrm{Ca}^{2+}$ - and $\mathrm{Mg}^{2+}$-free HBSS with $0.5 \%$ human serum albumin or in $\mathrm{Ca}^{2+}$ - and $\mathrm{Mg}^{2+}$-free HBSS with $0.5 \%$ human serum albumin, $20 \mathrm{mM}$ Hepes, and $1 \mathrm{mM}$ EGTA (pH 7.2-7.4) instead of control HBSS. Radiolabeled PMN were then added and incubated as indicated in Fig. 8. Calculation of the fraction of adherent PMN was done as described (40). In some experiments $\mathrm{H}_{2} \mathrm{O}_{2}$ or another agonist was added to suspensions of "In-labeled PMN overlying EC monolayers and adherence was determined after incubation at $37^{\circ} \mathrm{C}$ in $5 \% \mathrm{CO}_{2}, 95 \%$ air ("coincubation" experiments, Table II).

Measurement of the adherence of ${ }^{111}$ In-labeled PMN to cell-free surfaces was done by a minor modification of the method of Zimmerman et al. (42). The cell-free surfaces included tissue culture wells pretreated for $1 \mathrm{~h}$ at $37^{\circ} \mathrm{C}$ with 50 or $2000 \mu \mathrm{g} / \mathrm{ml}$ gelatin (Type A, Fischer Scientific Co.), $50 \mu \mathrm{g} / \mathrm{ml}$ human fibronectin (Collaborative Research, Inc., Waltham, MA) or whole human serum. Subendothelial matrices were prepared as described (42).

\section{Results}

$\mathrm{H}_{2} \mathrm{O}_{2}$ stimulates $B P A E C$ to synthesize $P A F$. In a preliminary experiment, we found that $\left[{ }^{3} \mathrm{H}\right.$-acetyl]PAF accumulation by HUVEC that were prelabeled with $\left[{ }^{3} \mathrm{H}\right]$ acetate and then incubated with PMN and ionophore A23187 (IoA, $10 \mu \mathrm{M}$ ) for 5 min was greater than when incubated with IoA alone, suggesting the possibility that IoA-stimulated PMN released an activity that enhanced PAF synthesis (EC + IoA, 1,250 $\pm 500 \mathrm{cpm}$; $\mathrm{PMN}+\mathrm{IoA}, 310 \pm 125 \mathrm{cpm} ; \mathrm{EC}+\mathrm{PMN}+\mathrm{IoA}, 6,400 \pm 700$ cpm; buffer-treated EC, PMN, or EC $+\mathrm{PMN}, 100 \pm 30 \mathrm{cpm}$ or less). In three subsequent experiments, we found that there was increased accumulation of $\left[{ }^{3} \mathrm{H}\right.$-acetyl $]$ PAF when EC were in- 
cubated in the presence of PMA-treated neutrophils (two- to fivefold increase over control, depending on time of incubation, ratio of PMN to EC, and concentrations of phorbol myristate acetate [PMA]). Since PMA did not stimulate PAF synthesis in EC or PMNs when incubated alone under these conditions, this result also suggests that a product of the activated PMN induced PAF synthesis. While the specific molecular specie(s) involved was not identified in these experiments, and conditions that might indicate its nature by inference were not included (i.e., the presence of $\mathrm{O}_{2}$ radical "scavengers" such as catalase, protease inhibitors, etc.), we considered the possibility that the activity was $\mathrm{H}_{2} \mathrm{O}_{2} \cdot \mathrm{H}_{2} \mathrm{O}_{2}$ is generated by neutrophils activated by IoA or PMA, and can alter membrane phospholipids in EC $(7,43)$. To determine if $\mathrm{H}_{2} \mathrm{O}_{2}$ can stimulate PAF synthesis in endothelium, we first examined its effect on bovine endothelial cells and found that cultured BPAEC reproducibly synthesized PAF when they were treated with $\mathrm{H}_{2} \mathrm{O}_{2}$. In 20 experiments, EC treated with $10 \mathrm{mM} \mathrm{H}_{2} \mathrm{O}_{2}$ for 30 min incorporated $8,948 \pm 5,089 \mathrm{cpm}$ of $\left[{ }^{3} \mathrm{H}\right]$ acetate into $\left[{ }^{3} \mathrm{H}\right.$ acetyl]PAF, compared with $386 \pm 221 \mathrm{cpm}$ in buffer-treated EC. The response was dependent on the concentration of $\mathrm{H}_{2} \mathrm{O}_{2}$ and demonstrated a narrow concentration-response relationship. There was consistent accumulation of $\left[{ }^{3} \mathrm{H}\right.$-acetyl]PAF at concentrations of $\mathrm{H}_{2} \mathrm{O}_{2}$ of $1-20 \mathrm{mM}$ with a maximal effect at 8-10 mM (Fig. 1). At concentrations of $\mathrm{H}_{2} \mathrm{O}_{2}$ above $10 \mathrm{mM}$, there was a concentration-dependent decrease in incorporation of labeled acetate (Fig. 1). In three experiments there were $1,033 \pm 513 \mathrm{cpm}$ in $\left[{ }^{3} \mathrm{H}\right.$-acetyl]PAF in BPAEC treated with $100 \mathrm{mM} \mathrm{H}_{2} \mathrm{O}_{2}$ compared with $10,333 \pm 3,177 \mathrm{cpm}$ in EC stimulated with $10 \mathrm{mM} \mathrm{H}_{2} \mathrm{O}_{2}$. There was no incorporation of $\left[{ }^{3} \mathrm{H}\right]$ acetate in BPAEC treated with 500 or $1,000 \mathrm{mM}$ $\mathrm{H}_{2} \mathrm{O}_{2}(n=2)$. The accumulation of $\left[{ }^{3} \mathrm{H}\right.$-acetyl $] \mathrm{PAF}$ in $\mathrm{H}_{2} \mathrm{O}_{2^{-}}$

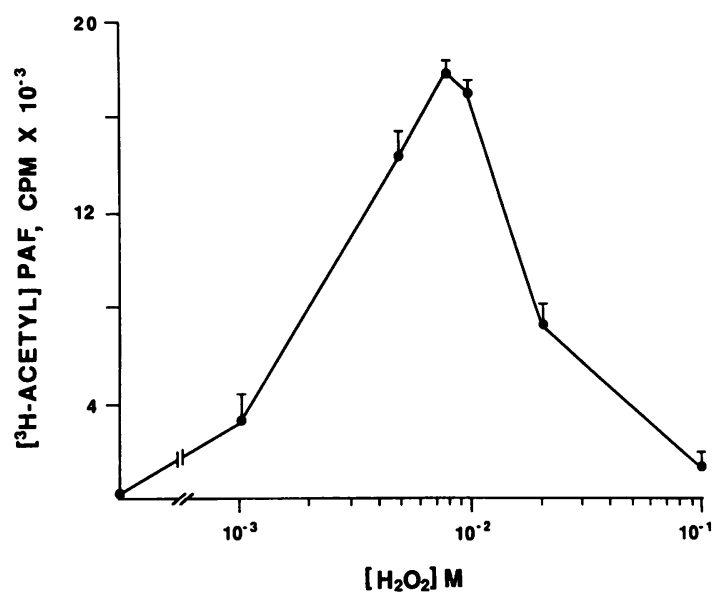

Figure 1. $\mathrm{H}_{2} \mathrm{O}_{2}$ stimulates the accumulation of $\left[{ }^{3} \mathrm{H}\right.$-acetyl $] \mathrm{PAF}$ by BPAEC. Confluent primary BPAEC monolayers were incubated in buffer containing $\left[{ }^{3} \mathrm{H}\right]$ acetate and various concentrations of $\mathrm{H}_{2} \mathrm{O}_{2}$ for $30 \mathrm{~min}$ at $37^{\circ} \mathrm{C}$. The incorporation of $\left[{ }^{3} \mathrm{H}\right]$ acetate into $\left[{ }^{3} \mathrm{H}\right.$-acetyl $]-$ PAF was measured as described in Methods. Each point represents the mean of duplicate determinations. Five additional experiments in which the effect of multiple concentrations of $\mathrm{H}_{2} \mathrm{O}_{2}$ were examined yielded similar results. In the experiment shown, the accumulation of $\left[{ }^{3} \mathrm{H}\right.$-acetyl $]$ PAF in BPAEC that were stimulated by 5 or 10 $\mathrm{mM} \mathrm{H}_{2} \mathrm{O}_{2}$ was $1,200 \pm 300$ and $100 \pm 50 \mathrm{cpm}$, respectively, when catalase $(500 \mathrm{U} / \mathrm{ml})$ was included in the incubation buffer, $a>90 \%$ reduction in each case.

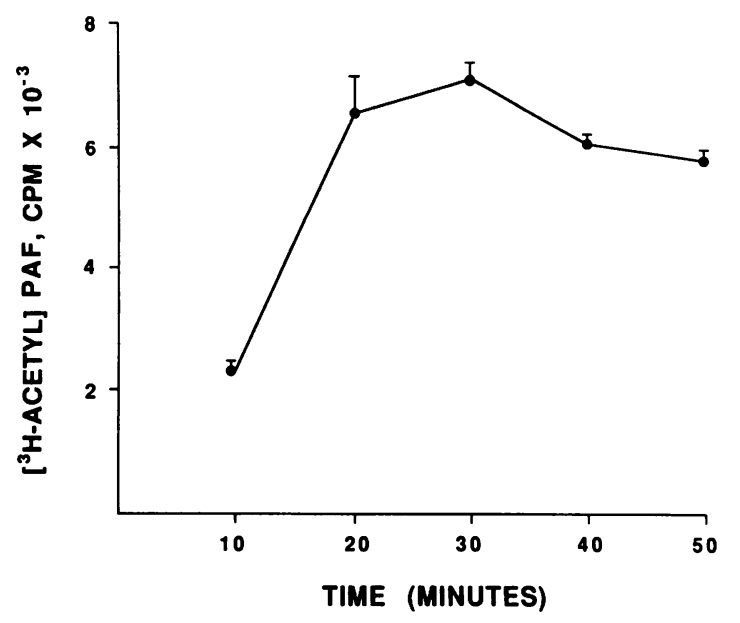

Figure 2. PAF synthesis by $\mathrm{H}_{2} \mathrm{O}_{2}$-stimulated BPAEC is dependent on the time of incubation. BPAEC were incubated in buffer containing $10 \mathrm{mM} \mathrm{H}_{2} \mathrm{O}_{2}$ and $\left[{ }^{3} \mathrm{H}\right.$ ]acetate for various times, indicated on the horizontal axis, and incorporation of the label into $\left[{ }^{3} \mathrm{H}\right.$-acetyl $] \mathrm{PAF}$ was determined as described in Methods. The points represent the means of duplicate determinations in a single experiment. At 30 min, there were $450 \pm 50 \mathrm{cpm}$ of $\left[{ }^{3} \mathrm{H}\right.$-acetyl]PAF in monolayers treated with control buffer.

simulated BPAEC was dependent on the time of incubation (Fig. 2). Maximal accumulation occurred at 20-30 min and then declined at a rate that varied from experiment to experiment (compare Fig. 2 with Figs. 5 and 6). However, significant amounts of $\left[{ }^{3} \mathrm{H}\right.$-acetyl]PAF were still present at 50 or $60 \mathrm{~min}$ in each of three experiments in which incubations were done for these periods.

To establish that $\mathrm{H}_{2} \mathrm{O}_{2}$ was the stimulus responsible for PAF synthesis, catalase was added to incubation solutions containing $\mathrm{H}_{2} \mathrm{O}_{2}$. We found that PAF synthesis by BPAEC was inhibited by $\sim 90 \%$ by coincubation with catalase (Fig. 1 , see legend; Table I). Inactivation of catalase by boiling prevented the inhibition (Table I). Furthermore, superoxide dismutase was largely ineffective in preventing $\mathrm{H}_{2} \mathrm{O}_{2}$-stimulated PAF synthesis (Table I). Incubation of BPAEC for $30 \mathrm{~min}$ in buffer containing glucose $(22 \mathrm{mM})$ and glucose-oxidase $(1,600$ $\mathrm{mU} / \mathrm{ml})$, a system that generates $\mathrm{H}_{2} \mathrm{O}_{2}(5,8,12)$, caused the accumulation of $4,800 \pm 400 \mathrm{cpm}\left[{ }^{3} \mathrm{H}\right.$-acetyl]PAF in the absence of catalase and $32 \pm 10 \mathrm{cpm}$ when catalase was present (duplicate determinations). Glucose/glucose oxidase also stimulated PAF accumulation in BPAEC in three additional experiments in which the concentration of glucose oxidase was varied between 100 and $1,600 \mathrm{mU} / \mathrm{ml}$. In two experiments treatment of BPAEC with bleomycin $\left(10^{-3} \mathrm{U} / \mathrm{ml}\right)$, a drug that may cause pulmonary vascular injury in part by the generation of oxygen radicals (2), or BCNU (1,3bis[chloroethyl]-nitrosourea; $50 \mathrm{mg} / \mathrm{ml}$ ), which may enhance $\mathrm{H}_{2} \mathrm{O}_{2}$-induced EC injury by disrupting the glutathione redox cycle (8), caused a two- to fivefold potentiation of PAF accumulation in response to $10 \mathrm{mM} \mathrm{H}_{2} \mathrm{O}_{2}$. Neither drug potentiated PAF accumulation stimulated by bradykinin (33) in parallel incubations.

$\mathrm{H}_{2} \mathrm{O}_{2}$, and $\mathrm{H}_{2} \mathrm{O}_{2}$-generating systems, have previously been reported to stimulate $\mathrm{EC}$ to synthesize $\mathrm{PGI}_{2}(43)$, and we have found that the synthesis of $\mathbf{P G I}_{2}$ and PAF are concordant events in activated human and bovine endothelium $(22,23)$. In an experiment to test this association with $\mathrm{H}_{2} \mathrm{O}_{2}$ as the 
Table I. $\mathrm{H}_{2} \mathrm{O}_{2}$-stimulated PAF Synthesis by BPAEC Is Inhibited by Catalase and Is Dependent on Extracellular Divalent Cations

\begin{tabular}{|c|c|c|c|}
\hline Experiment & Condition & {$\left[{ }^{3} \mathrm{H}-a c e t y l\right]$ PAF } & Change \\
\hline & & $\mathrm{cpm}$ & $\%$ \\
\hline \multirow[t]{5}{*}{ I } & Control buffer & $600 \pm 150$ & \\
\hline & $\mathrm{H}_{2} \mathrm{O}_{2}(10 \mathrm{mM})$ & $13,000 \pm 100$ & \\
\hline & $\mathrm{H}_{2} \mathrm{O}_{2}(10 \mathrm{mM})+$ catalase & $900 \pm 300$ & -98 \\
\hline & $\mathrm{H}_{2} \mathrm{O}_{2}(10 \mathrm{mM})+$ inactive & $11.700+200$ & -10 \\
\hline & $\mathrm{H}_{2} \mathrm{O}_{2}(10 \mathrm{mM})+\mathrm{SOD}$ & $8,700 \pm 150$ & -33 \\
\hline \multirow[t]{4}{*}{ II } & Control buffer & $300 \pm 50$ & \\
\hline & $\mathrm{H}_{2} \mathrm{O}_{2}(10 \mathrm{mM})$ & 5,400 & \\
\hline & $\mathrm{H}_{2} \mathrm{O}_{2}(10 \mathrm{mM})+$ catalase & $350 \pm 200$ & -99 \\
\hline & $\mathrm{H}_{2} \mathrm{O}_{2}(10 \mathrm{mM})+\mathrm{SOD}$ & 6,000 & +11 \\
\hline \multirow[t]{10}{*}{ III } & Control buffer & $400 \pm 150$ & \\
\hline & $\mathrm{H}_{2} \mathrm{O}_{2}(7.5 \mathrm{mM})$ & $9,800 \pm 800$ & \\
\hline & $\mathrm{H}_{2} \mathrm{O}_{2}(7.5 \mathrm{mM}), \mathrm{Ca}^{2+}$ & & \\
\hline & $\mathrm{Mg}^{2+}$-free buffer & $350 \pm 75$ & -100 \\
\hline & $\mathrm{H}_{2} \mathrm{O}_{2}(10 \mathrm{mM})$ & $14,000 \pm 2,000$ & \\
\hline & $\mathrm{H}_{2} \mathrm{O}_{2}(10 \mathrm{mM}), \mathrm{Ca}^{2+}$ & & \\
\hline & $\mathrm{Mg}^{2+}$-free buffer & $100 \pm 50$ & -100 \\
\hline & $\mathrm{H}_{2} \mathrm{O}_{2}(25 \mathrm{mM})$ & $1,200 \pm 75$ & \\
\hline & $\mathrm{H}_{2} \mathrm{O}_{2}(25 \mathrm{mM}), \mathrm{Ca}^{2+}$ & & \\
\hline & $\mathrm{Mg}^{2+}$-free buffer & $75 \pm 10$ & -100 \\
\hline
\end{tabular}

BPAEC were incubated in control buffer, buffer containing $\mathrm{H}_{2} \mathrm{O}_{2}$ with or without catalase $(500 \mathrm{U} / \mathrm{ml})$, or $\operatorname{SOD}(500 \mathrm{U} / \mathrm{ml})$, or in control or $\mathrm{Ca}^{2+}$ - and $\mathrm{Mg}^{2+}$-free buffer with $\mathrm{H}_{2} \mathrm{O}_{2}$, for $30 \mathrm{~min}$. In one experiment catalase was inactivated by boiling. Incorporation of $\left[{ }^{3} \mathrm{H}\right]-$ acetate into $\left[{ }^{3} \mathrm{H}\right.$-acetyl]PAF was measured as described in Methods. Values indicate single determinations or mean \pm SD of duplicate determinations. Values for $\left[{ }^{3} \mathrm{H}\right.$-acetyl]PAF in EC treated with control buffer were subtracted from PAF levels in EC stimulated with $\mathrm{H}_{2} \mathrm{O}_{2}$ when the "change" was calculated.

agonist, we found that $10 \mathrm{mM} \mathrm{H}_{2} \mathrm{O}_{2}$ stimulated the release of 6-keto- $\mathrm{PGF}_{1 \alpha}$ (measured by radioimmunoassay; reference 22 ) and accumulation of $\left[{ }^{3} \mathrm{H}\right.$-acetyl $] \mathrm{PAF}$ in parallel, with a maximal accumulation of each at $20 \mathrm{~min}$.

$\mathrm{H}_{2} \mathrm{O}_{2}$ stimulates ${ }^{45} \mathrm{Ca}^{2+}$ uptake by BPAEC. PAF synthesis by BPAEC in response to $\mathrm{H}_{2} \mathrm{O}_{2}$ was dependent on extracellular divalent cations. When $\mathrm{H}_{2} \mathrm{O}_{2}$ was incubated in both submaximal and maximal concentrations with BPAEC monolayers in $\mathrm{Ca}^{2+}$ - and $\mathrm{Mg}^{2+}$-free buffer, the accumulation of PAF was completely inhibited (Table I). PAF synthesis by endothelium stimulated by other agonists, including the receptor-mediated ligands bradykinin and ATP and the calcium IoA, is dependent on extracellular $\mathrm{Ca}^{2+}$; furthermore, these agonists stimulate $\mathrm{Ca}^{2+}$ uptake by $\mathrm{EC}$ (Whatley et al., manuscript submitted for publication). To determine if $\mathrm{H}_{2} \mathrm{O}_{2}$ also induces calcium transfer, we stimulated BPAEC monolayers in buffer containing ${ }^{45} \mathrm{Ca}^{2+}$ and found a time-dependent increase in labeled calcium associated with the cells (Fig. $3 \mathrm{~A}$ ). Ionophore A23187 (IoA) also stimulated ${ }^{45} \mathrm{Ca}^{2+}$ uptake in parallel incubations. A second experiment yielded qualitatively similar results. To further demonstrate that $\mathrm{H}_{2} \mathrm{O}_{2}$ increased the permeability of $\mathrm{EC}$ plasma membranes to $\mathrm{Ca}^{2+}$, we preloaded the cells with ${ }^{45} \mathrm{Ca}^{2+}$ and then treated them with $\mathrm{H}_{2} \mathrm{O}_{2}$ or IoA in calcium-free

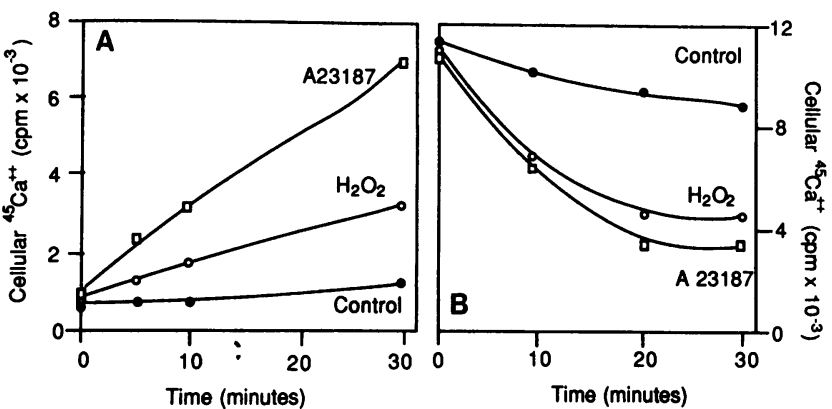

Figure 3. Endothelial cells stimulated with $\mathrm{H}_{2} \mathrm{O}_{2}$ have increased calcium permeability. $(A) \mathrm{H}_{2} \mathrm{O}_{2}$-stimulated ${ }^{45} \mathrm{Ca}^{2+}$ uptake by BPAEC. Bovine pulmonary artery endothelial cells $\left(10^{6}\right.$ cells per dish) were incubated at $25^{\circ} \mathrm{C}$ in the presence of ${ }^{45} \mathrm{Ca}^{2+}(5 \mu \mathrm{Ci} / \mathrm{ml})$ in HBSS containing control buffer, $\mathrm{H}_{2} \mathrm{O}_{2}(10 \mathrm{mM})$, or calcium ionophore $\mathrm{A} 23187$ $\left(10^{-5} \mathrm{M}\right)$. At the indicated times, the incubation buffer was removed and the cellular ${ }^{45} \mathrm{Ca}^{2+}$ content determined as described in Methods. Each point represents a single determination in one dish. The results shown are representative of two separate experiments. $(B) \mathrm{H}_{2} \mathrm{O}_{2-}$ stimulated ${ }^{45} \mathrm{Ca}^{2+}$ efflux from preloaded BPAEC. Bovine pulmonary artery cells were incubated in medium containing $5 \mu \mathrm{Ci} / \mathrm{ml}^{45} \mathrm{Ca}^{2+}$ for $1 \mathrm{~h}$ at $37^{\circ} \mathrm{C}$. The incubation medium was removed, the monolayers were washed with $\mathrm{HBSS}$, and were then incubated at $25^{\circ} \mathrm{C}$ in calcium-free control buffer (HBSS, pH 7.4) or the same buffer containing $\mathrm{H}_{2} \mathrm{O}_{2}(10 \mathrm{mM})$ or calcium ionophore A23187 $\left(10^{-5} \mathrm{M}\right)$. At the indicated times, the incubation buffer was removed and the ${ }^{45} \mathrm{Ca}^{2+}$ content was determined as described in Methods.

buffer. This maneuver created a large concentration gradient between $\mathrm{Ca}^{2+}$ in the cytoplasm and the extracellular space; under these conditions increased plasma membrane permeability to calcium would result in efflux of $\mathrm{Ca}^{2+}$ from the cell. Stimulation of the EC with $10 \mathrm{mM} \mathrm{H}_{2} \mathrm{O}_{2}$ resulted in loss of labeled $\mathrm{Ca}^{2+}$ from the cells, as did treatment with the ionophore (Fig. $3 \mathrm{~B}$ ). These experiments demonstrate that $\mathrm{H}_{2} \mathrm{O}_{2}$ induces increased permeability of EC membranes for $\mathrm{Ca}^{2+}$ and/or that it activates calcium transport mechanisms that cause both uptake and extrusion. The alterations in $\mathrm{Ca}^{2+}$ transport were temporally associated with PAF synthesis (Fig. 2).

$\mathrm{H}_{2} \mathrm{O}_{2}$-induced $\mathrm{PAF}$ synthesis by BPAEC is temporally dissociated from lytic cell injury. BPAEC, when subjected to concentrations of $\mathrm{H}_{2} \mathrm{O}_{2}$ that induced maximal synthesis of PAF (Fig. 1), exhibited no morphologic evidence of injury such as swelling, detachment from the monolayer, or lysis. Moreover, trypan blue was excluded by EC stimulated with $\mathrm{H}_{2} \mathrm{O}_{2}$ in this concentration range (Fig. 4). This finding indicates that the synthesis of PAF is not simply a consequence of plasma membrane disruption, and that the increased permeability to $\mathrm{Ca}^{2+}$ (previous section) was selective rather than nonspecific. There was a parallel increase in abnormal cell morphology and trypan blue uptake above $\mathrm{H}_{2} \mathrm{O}_{2}$ concentrations of $20 \mathrm{mM}$, accompanying the dramatic fall in PAF accumulation at these concentrations (Fig. 4). A time course of PAF accumulation compared to trypan blue uptake in response to $10 \mathrm{mM} \mathrm{H}_{2} \mathrm{O}_{2}$ demonstrated that there was minimal uptake of the dye at the time of maximal PAF accumulation, followed by a progressive increase in trypan blue uptake during the descending slope of the PAF accumulation curve (Fig. 5).

$P A F$ remains associated with the cells in $\mathrm{H}_{2} \mathrm{O}_{2}$-stimulated $B P A E C$ monolayers. Newly synthesized PAF remains associated with human $(22,23,41)$ and bovine (33) EC stimulated 


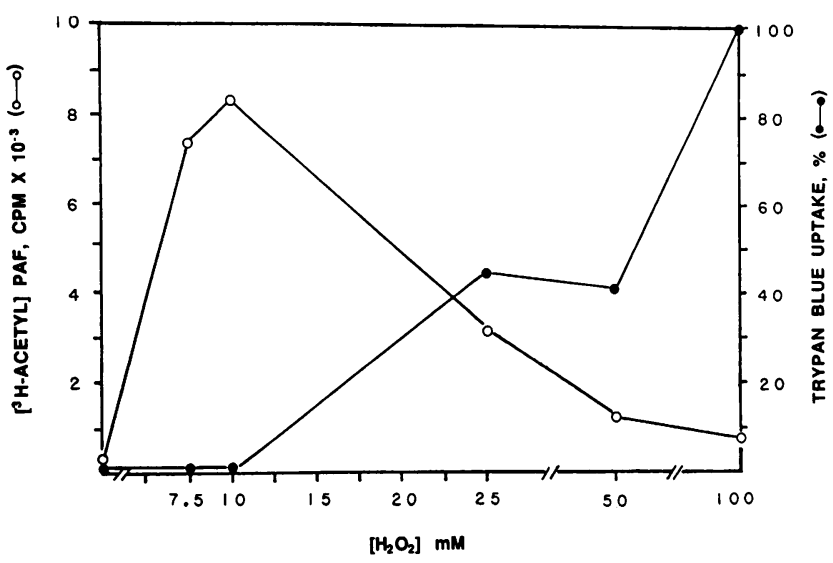

Figure 4. Maximal PAF synthesis by $\mathrm{H}_{2} \mathrm{O}_{2}$-treated BPAEC is dissociated from increased permeability to trypan blue. BPAEC monolayers were treated with buffer containing various concentrations of $\mathrm{H}_{2} \mathrm{O}_{2}$ and $\left[{ }^{3} \mathrm{H}\right]$ acetate for $30 \mathrm{~min}$ at $37^{\circ} \mathrm{C}$ and $\left[{ }^{3} \mathrm{H}\right.$-acetyl $] \mathrm{PAF}$ accumulation was measured as described in Methods. Trypan blue staining was done by a minor modification of a described technique (39); uptake was determined by phase-contrast microscopy (300-500 cells were counted in each monolayer) and is expressed as the percentage of cells with blue staining.

with a variety of agonists that interact with plasma membrane receptors. However, it is possible that it may be released from EC that are injured by oxidants or other pathologic stimuli (44). To determine if PAF synthesized by $\mathrm{H}_{2} \mathrm{O}_{2}$-stimulated BPAEC is released into the fluid phase, we incubated EC monolayers with $\mathrm{H}_{2} \mathrm{O}_{2}$ for various periods and measured the fractions of $\left[{ }^{3} \mathrm{H}\right.$-acetyl $] \mathrm{PAF}$ in the incubation buffer and in the cells after they were extracted separately. In four experiments, $1 \%$ or less of the labeled PAF was found in the incubation medium after stimulation of the EC with $10 \mathrm{mM} \mathrm{H}_{2} \mathrm{O}_{2}$ for 30 $\min$ at $37^{\circ} \mathrm{C}$. We found a similar result when $30 \mathrm{mg} / \mathrm{ml}$ fatty acid-free bovine serum albumin, to which PAF binds, was included in the incubation buffer. In an experiment to examine the time dependency of the distribution of newly synthesized PAF in $\mathrm{H}_{2} \mathrm{O}_{2}$-stimulated BPAEC, the phospholipid re-

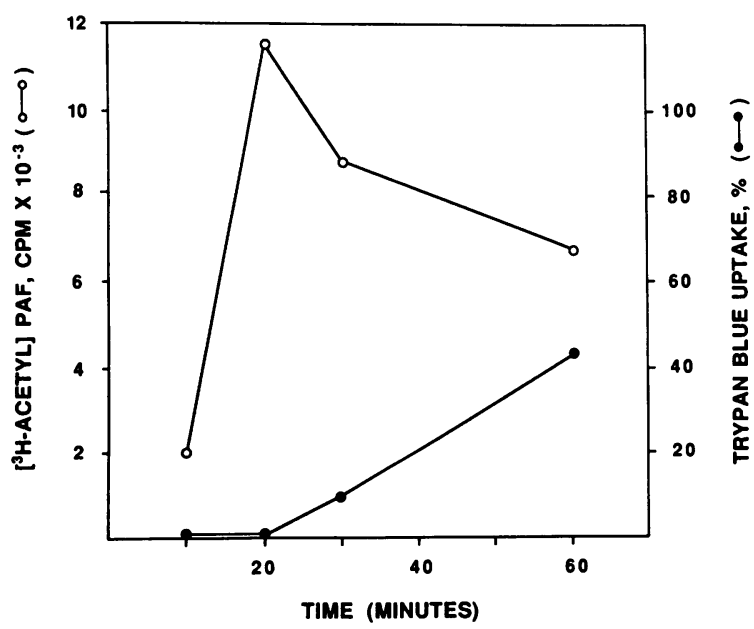

Figure 5. The time-dependent alterations in PAF accumulation and trypan blue uptake are dissociated in $\mathrm{H}_{2} \mathrm{O}_{2}$-stimulated BPAEC. $\left[{ }^{3} \mathrm{H}\right.$ acetyl]PAF accumulation and trypan blue uptake were measured as described in Fig. 4 in replicate BPAEC monolayers that were stimulated with $10 \mathrm{mM} \mathrm{H}_{2} \mathrm{O}_{2}$. mained associated with the cell pellet at all time points and little, if any, was released into the incubation medium (Fig. 6). Even at $60 \mathrm{~min}$, when as many as $40 \%$ of the EC treated with $10 \mathrm{mM} \mathrm{H}_{2} \mathrm{O}_{2}$ may be permeable to trypan blue (mol wt 961 ) (Fig. 5), PAF ( $\mathrm{mol} \mathrm{wt}=524)$ was retained by the endothelium.

$\mathrm{H}_{2} \mathrm{O}_{2}$ stimulates $\mathrm{PAF}$ synthesis by human endothelium. HUVEC were used as a readily available human cell type that shares many common features with in situ endothelium and with endothelium cultured from other human vessels (19). We found that $\mathrm{H}_{2} \mathrm{O}_{2}$ reproducibly stimulated $\left[{ }^{3} \mathrm{H}\right]$ acetate incorporation into $\left[{ }^{3} \mathrm{H}\right.$-acetyl]PAF in these cells. The response was concentration-dependent with a threshold at $0.5-1 \mathrm{mM} \mathrm{H}_{2} \mathrm{O}_{2}$, a maximal effect at 5-10 $\mathrm{mM} \mathrm{H}_{2} \mathrm{O}_{2}$, and a sharp decrease at $100 \mathrm{mM} \mathrm{H}_{2} \mathrm{O}_{2}$. In contrast, $\mathrm{H}_{2} \mathrm{O}_{2}(1-100 \mathrm{mM})$ did not stimulate $\left[{ }^{3} \mathrm{H}\right.$-acetyl $]$ PAF accumulation in isolated human PMN, even though PMN synthesize PAF in response to several agonists (36), indicating a degree of specificity of the $\mathrm{H}_{2} \mathrm{O}_{2}$ effect. PAF accumulation by $\mathrm{H}_{2} \mathrm{O}_{2}$-stimulated HUVEC was also time-dependent. In each of five experiments maximal [ ${ }^{3} \mathrm{H}$-acetyl]PAF occurred at $10-20 \mathrm{~min}$ in response to $10 \mathrm{mM}$ $\mathrm{H}_{2} \mathrm{O}_{2}$, followed by a variable decline to basal, or near basal, levels by 60 min (Fig. 7). Thus the accumulation of PAF in HUVEC stimulated with a maximal concentration of $\mathrm{H}_{2} \mathrm{O}_{2}$ was usually more abbreviated than in BPAEC (Figs. 2, 5, and 6). In an experiment comparing submaximal and maximal concentrations of $\mathrm{H}_{2} \mathrm{O}_{2}(1$ and $10 \mathrm{mM})$ in HUVEC, there was a broader and more prolonged time course in response to the lower concentration of $\mathrm{H}_{2} \mathrm{O}_{2}$ (Fig. 7).

HUVEC treated with $10 \mathrm{mM} \mathrm{H}_{2} \mathrm{O}_{2}$ excluded trypan blue during the first $60 \mathrm{~min}$ of incubation, the period of PAF accumulation, and the monolayers remained intact. The response thereafter was variable. In one experiment essentially all cells were permeable to trypan blue, and there was extensive detachment and lysis of the EC, by $120 \mathrm{~min}$. In two additional

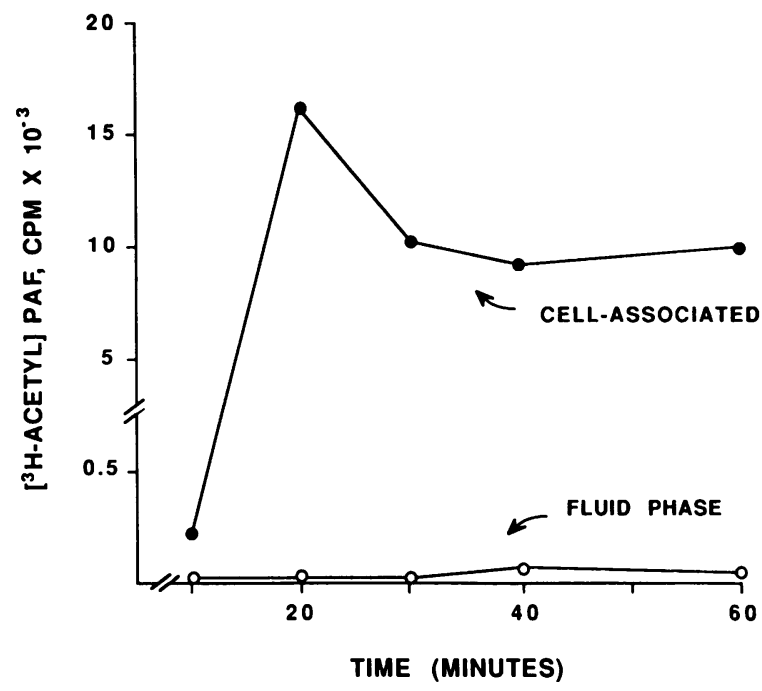

Figure 6. PAF synthesized by $\mathrm{H}_{2} \mathrm{O}_{2}$-stimulated BPAEC is cell-associated. EC monolayers were incubated with $10 \mathrm{mM} \mathrm{H}_{2} \mathrm{O}_{2}$ and $\left[{ }^{3} \mathrm{H}\right]-$ acetate for various times at $37^{\circ} \mathrm{C}$. At the end of the incubation periods the buffer was removed, the lipids in the buffer and EC monolayers were separately extracted, and the amount of $\left[{ }^{3} \mathrm{H}\right.$-acetyl $] \mathrm{PAF}$ was determined in each. The points indicate the mean of duplicate determinations in a single experiment. A qualitatively similar result was found in a second experiment in which the incubations were stopped at 10,30 , and $50 \mathrm{~min}$. 


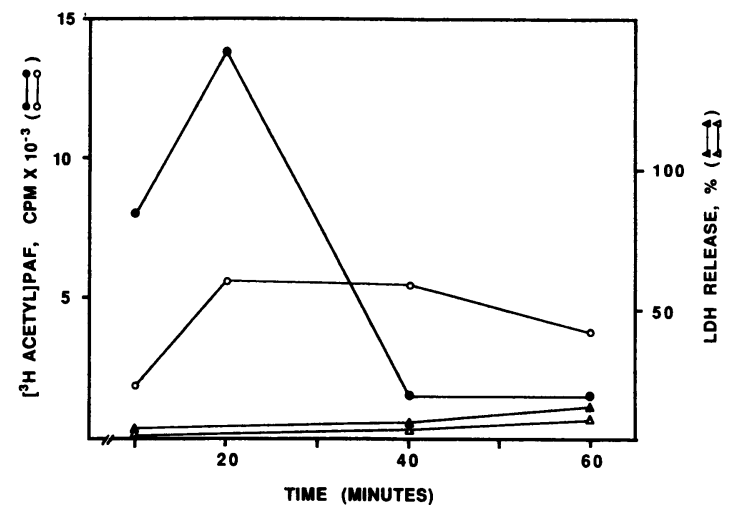

Figure 7. $\mathrm{H}_{2} \mathrm{O}_{2}$-induced $\left[{ }^{3} \mathrm{H}\right.$-acetyl $] \mathrm{PAF}$ accumulation in human endothelium is dissociated from cytolytic injury. HUVEC were incubated with $1 \mathrm{mM}(0, \Delta)$ or $10 \mathrm{mM}(\bullet, \Delta) \mathrm{H}_{2} \mathrm{O}_{2}$ and $\left[{ }^{3} \mathrm{H}\right]$ acetate, and the accumulation of $\left[{ }^{3} \mathrm{H}\right.$-acetyl $] \mathrm{PAF}$ was measured as described in Methods. LDH was measured (36) in the cell fraction (after solubilization with Triton X-100) and in the incubation buffer of replicate monolayers and the fraction that was released into the incubation buffer was calculated. EC treated with control buffer in the absence of $\mathrm{H}_{2} \mathrm{O}_{2}$ released no LDH at 10 or $60 \mathrm{~min}$.

experiments EC developed altered morphology (retracted, angular cells) after $2 \mathrm{~h}$, but significant desquamation of EC and trypan blue uptake did not occur until 3-6 h after treatment of the EC with $\mathrm{H}_{2} \mathrm{O}_{2}$. In addition, in two experiments $\mathrm{EC}$ were treated with $10 \mathrm{mM} \mathrm{H}_{2} \mathrm{O}_{2}$ for $20 \mathrm{~min}$, incubated with catalase $\left(500 \mathrm{U} / \mathrm{ml}\right.$, to degrade any remaining extracellular $\left.\mathrm{H}_{2} \mathrm{O}_{2}\right)$ or control buffer for $10 \mathrm{~min}$, and then covered with complete culture medium and returned to the incubator for $18 \mathrm{~h}$. In both experiments there was an adherent monolayer of EC that excluded trypan blue at the end of this period, although individual cells had been lost from the monolayer and many cells had undergone shape change; there was no obvious difference in monolayers "rescued" with catalase and complete medium compared to complete medium alone. These experiments indicated that PAF synthesis was temporally dissociated from lethal injury to the EC assessed by trypan blue uptake and from complete morphologic disruption of the monolayer. Significant $\mathrm{LDH}$ release was a late event that was also dissociated from PAF synthesis. $8 \%$ and $12 \%$ of total cellular LDH was released from HUVEC treated with $1 \mathrm{mM}$ or $10 \mathrm{mM} \mathrm{H}_{2} \mathrm{O}_{2}$ for $60 \mathrm{~min}$ (Fig. 7). In a second experiment there was no LDH release and maximal PAF accumulation when HUVEC monolayers were stimulated with $10 \mathrm{mM} \mathrm{H}_{2} \mathrm{O}_{2}$ for $10 \mathrm{~min}$, whereas there was decreased PAF accumulation in association with increased LDH release in response to 100 and $500 \mathrm{mM}$ $\mathrm{H}_{2} \mathrm{O}_{2}\left(90 \% \mathrm{LDH}\right.$ release from EC treated with $500 \mathrm{mM} \mathrm{H}_{2} \mathrm{O}_{2}$ ). Thus in HUVEC, as in BPAEC, PAF synthesis was temporally dissociated from indices of extensive plasma membrane damage and cytolytic injury. Also as in $\mathrm{H}_{2} \mathrm{O}_{2}$-stimulated BPAEC, the newly synthesized $\left[{ }^{3} \mathrm{H}\right.$-acetyl] PAF was retained by the EC (not shown).

In an experiment to determine the effect of pretreatment of EC with $\mathrm{H}_{2} \mathrm{O}_{2}$ on subsequent PAF synthesis stimulated by receptor-mediated agonists, we pretreated HUVEC with 0.5 or $3 \mathrm{mM} \mathrm{H}_{2} \mathrm{O}_{2}$ for $10 \mathrm{~min}$, removed the buffer, and added human $\alpha$-thrombin $(2.0 \mathrm{U} / \mathrm{ml})(20,42)$ for an additional 10 -min incubation. Pretreatment with 0.5 or $3 \mathrm{mM} \mathrm{H}_{2} \mathrm{O}_{2}$ reduced PAF accumulation by $47 \%$ and $51 \%$, respectively, compared to the thrombin response in replicate monolayers pretreated with control buffer.

$\mathrm{H}_{2} \mathrm{O}_{2}$ induces endothelial cell-dependent neutrophil adhesion. We have previously observed that the synthesis of PAF by HUVEC is tightly coupled with a functional alteration that results in the adhesion of neutrophils (PMN) to the EC (20, 40-42), suggesting that the two events are related and that they are components of a rapid EC activation response (23). To determine if $\mathrm{H}_{2} \mathrm{O}_{2}$ induces endothelial cell-dependent neutrophil adhesion, we pretreated HUVEC monolayers for $20 \mathrm{~min}$ with $\mathrm{H}_{2} \mathrm{O}_{2}(10 \mathrm{mM})$; the $\mathrm{H}_{2} \mathrm{O}_{2}$ was then removed and replaced with buffer containing ${ }^{111}$ In-labeled PMN. Neutrophil adhesion was measured after a 5-min incubation. In eight experiments, this resulted in a two- to sixfold increase in the adhesion of labeled PMN when compared to adherence to EC pretreated with control buffer (Table II). Examination of the monolayers by phase-contrast microscopy demonstrated that single neutrophils adhered to the surface of the EC, with rare aggregates of PMN also adhering, and that the monolayers were intact at this time. The response was concentration-dependent (Fig. 8) with a threshold at $0.5-1.0 \mathrm{mM} \mathrm{H}_{2} \mathrm{O}_{2}$ and a maximal effect at 5-10 $\mathrm{mM} \mathrm{H}_{2} \mathrm{O}_{2}$. Pretreatment of HUVEC with $100 \mathrm{mM} \mathrm{H}_{2} \mathrm{O}_{2}$ resulted in PMN adherence that was con-

Table II. $\mathrm{H}_{2} \mathrm{O}_{2}$ Induces EC-dependent PMN Adhesion

\begin{tabular}{lcc}
\hline \multicolumn{1}{c}{ Condition } & $\begin{array}{c}\text { Adhesion } \\
(\text { Mean } \pm \text { SD })\end{array}$ & $\begin{array}{c}\text { Experiments } \\
(n)\end{array}$ \\
\hline & $\%$ & \\
I. Pretreatment & & \\
EC + buffer & $7 \pm 3$ & 8 \\
EC $+\mathrm{H}_{2} \mathrm{O}_{2}(5 \mathrm{mM})$ & $24 \pm 8$ & 8 \\
EC $+\mathrm{H}_{2} \mathrm{O}_{2}(10 \mathrm{mM})$ & $25 \pm 7$ & 8 \\
EC $+\mathrm{H}_{2} \mathrm{O}_{2}(10 \mathrm{mM})$, wash & $27 \pm 0.4$ & 2 \\
EC $+\mathrm{H}_{2} \mathrm{O}_{2}(10 \mathrm{mM})$, catalase & $9 \pm 3$ & 4 \\
EC $+\mathrm{H}_{2} \mathrm{O}_{2}(10 \mathrm{mM})$, SOD & $25 \pm 4$ & 2 \\
II. Cell-free surfaces & & \\
CFS + PMN + buffer & $6 \pm 3$ & 8 \\
CFS + PMN $+\mathrm{H}_{2} \mathrm{O}_{2}(1 \mathrm{mM})$ & $6 \pm 2$ & 5 \\
CFS + PMN $+\mathrm{H}_{2} \mathrm{O}_{2}(5 \mathrm{mM})$ & $8 \pm 3$ & 5 \\
CFS + PMN $+\mathrm{H}_{2} \mathrm{O}_{2}(10 \mathrm{mM})$ & $8 \pm 4$ & 8 \\
III. Coincubation & & \\
EC + PMN + buffer & $8 \pm 4$ & 2 \\
EC + PMN $+\mathrm{H}_{2} \mathrm{O}_{2}(5 \mathrm{mM})$ & $15 \pm 2$ & 2 \\
EC + PMN $+\mathrm{H}_{2} \mathrm{O}_{2}(10 \mathrm{mM})$ & $22 \pm 0$ & 2 \\
\hline
\end{tabular}

In pretreatment protocols, EC monolayers were incubated with control buffer (HBSS $/ 0.5 \%$ human serum albumin) or $\mathrm{H}_{2} \mathrm{O}_{2}$ in HBSS $/ 0.5 \%$ human serum albumin for $20 \mathrm{~min}$ at $37^{\circ} \mathrm{C}$; the incubation mixture was then removed, ${ }^{11}$ In-labeled PMNs were added and incubated for $5 \mathrm{~min}$, and adherence determined as in Methods and Fig. 8. In some experiments EC were washed with 1 or 2 vol of HBSS $/ 0.5 \%$ human serum albumin after incubation with $\mathrm{H}_{2} \mathrm{O}_{2}$, before addition of $\mathrm{PMN}$; in other experiments catalase $(500 \mathrm{U} / \mathrm{ml})$ or SOD $(500 \mathrm{U} / \mathrm{ml})$ was included in the incubation mixture with $\mathrm{H}_{2} \mathrm{O}_{2}$. In experiments with cell-free surfaces (CFS), ${ }^{111}$ In-labeled PMN were added to gelatin-coated culture wells, buffer or $\mathrm{H}_{2} \mathrm{O}_{2}$ was added, and PMN adherence was measured after 5 min of incubation. In coincubation protocols, control buffer or $\mathrm{H}_{2} \mathrm{O}_{2}$ was added to "II In-labeled PMN overlying EC monolayers and PMN adherence was determined after a 20-min incubation. 


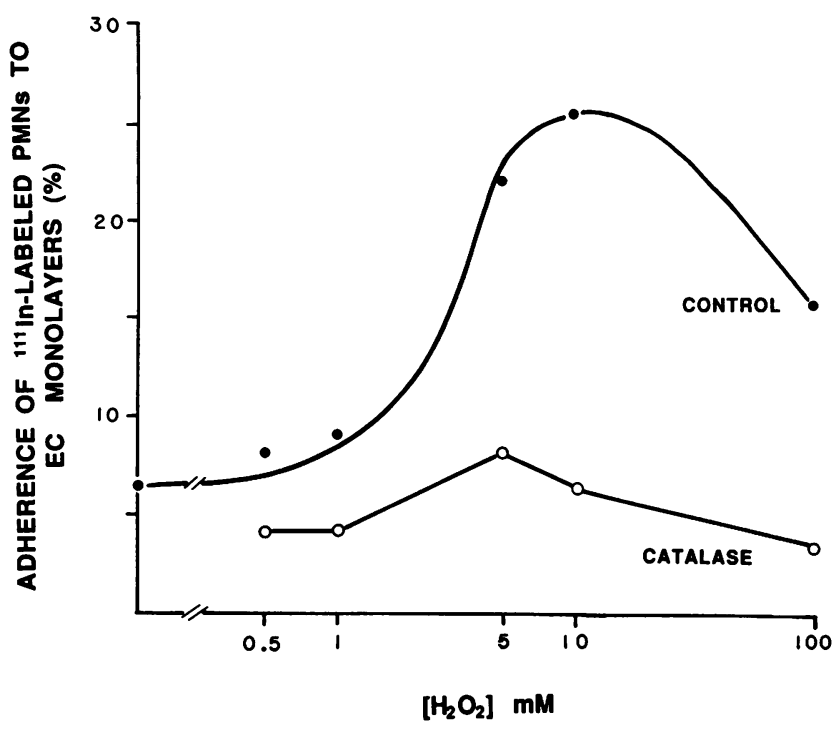

Figure 8. Endothelial cell-dependent PMN adherence is induced by $\mathrm{H}_{2} \mathrm{O}_{2}$ in a concentration-dependent fashion. HUVEC were pretreated with control buffer (HBSS/ $0.5 \%$ human serum albumin) or with various concentrations of $\mathrm{H}_{2} \mathrm{O}_{2}$ diluted in $\mathrm{HBSS} / 0.5 \%$ human serum albumin for $20 \mathrm{~min}$ at $37^{\circ} \mathrm{C}$. Catalase $(500 \mathrm{U} / \mathrm{ml})$ was included in some incubations. The incubation mixtures were then removed and ${ }^{111}$ In-labeled PMNs $\left(5.5 \times 10^{6} / \mathrm{ml}\right.$ in HBSS $/ 0.5 \%$ human serum albumin) were added and incubated for an additional $5 \mathrm{~min}$. The fraction of adherent PMNs was determined as described (40) after confirming that the leukocytes had adhered to the surface of the EC by inspection (phase-contrast microscopy). The means of results from two experiments are shown.

siderably lower than adhesion induced by $10 \mathrm{mM} \mathrm{H}_{2} \mathrm{O}_{2}(12 \%$ vs. $25 \%, n=5$ and 8 , respectively), a pattern similar to that seen when PAF accumulation was assayed. $\mathrm{H}_{2} \mathrm{O}_{2}$-induced PMN adhesion was inhibited by catalase (Fig. 8; Table II) but not by SOD (Table II). Incubation of EC with $\mathrm{H}_{2} \mathrm{O}_{2}$ in divalent cation-free buffer completely inhibited subsequent PMN adhesion; addition of $\mathrm{Ca}^{2+}$, but not $\mathrm{Mg}^{2+}$, returned the response to control levels. Direct addition of $10 \mathrm{mM} \mathrm{H}_{2} \mathrm{O}_{2}$ to PMN suspensions overlying HUVEC monolayers, followed by a 20 min incubation, also stimulated PMN adhesion, but the adherence under these conditions was less than in parallel incubations where $\mathrm{EC}$ were pretreated with $\mathrm{H}_{2} \mathrm{O}_{2}$ for 20 min before addition of the PMN (Table II). This may be in part due to the generation of $\mathrm{PGI}_{2}$, which can blunt PMN adhesiveness (45), by the $\mathrm{H}_{2} \mathrm{O}_{2}$-stimulated EC, or to the ability of PMN to "scavenge" $\mathrm{H}_{2} \mathrm{O}_{2}$ (46).

Washing of the EC monolayers with buffer after pretreatment with $\mathrm{H}_{2} \mathrm{O}_{2}$ did not diminish PMN adhesion when the leukocytes were subsequently added and incubated for $5 \mathrm{~min}$ (Table II). In addition, $\mathrm{H}_{2} \mathrm{O}_{2}$ did not cause $\mathrm{PMN}$ to adhere to cell-free surfaces (gelatin-coated tissue culture wells) when it was added to the PMN and they were incubated for the same period as in incubations with EC (Table II); this excludes the possibility that "carryover" of $\mathrm{H}_{2} \mathrm{O}_{2}$ directly induced increased PMN adhesiveness. Pretreatment of subendothelial matrices or incubation wells coated with gelatin $(50 \mathrm{mg} / \mathrm{ml}), \mathrm{Fn}(50$ $\mathrm{mg} / \mathrm{ml}$ ), or whole human serum (used as a source of vitronectin and thrombospondin as well as vWF and Fn) with $10 \mathrm{mM}$ $\mathrm{H}_{2} \mathrm{O}_{2}$ for 20 min followed by the addition of PMN for $5 \mathrm{~min}$ did not cause increased PMN adhesion compared to surfaces pretreated with control buffer $(n=2)$. Thus, under the conditions of these experiments, the $\mathrm{H}_{2} \mathrm{O}_{2}$-stimulated PMN adhesion resulted from increased adhesiveness of the endothelium and was dependent on the EC.

The $\mathrm{H}_{2} \mathrm{O}_{2}$-induced neutrophil adhesion was a time-dependent event. Pretreatment of the HUVEC with $10 \mathrm{mM} \mathrm{H}_{2} \mathrm{O}_{2}$ for as little as $5 \mathrm{~min}$ resulted in enhanced leukocyte binding. Although there was variation from experiment to experiment, the maximal effect was at 20 min and PMN adhesion declined when the monolayers were pretreated for longer periods. This temporal pattern was similar to the time course of $\mathrm{H}_{2} \mathrm{O}_{2}$-stimulated PAF accumulation in HUVEC. Therefore, we measured PAF accumulation and neutrophil adhesion in parallel using replicate EC monolayers from the same culture. The two responses were concordant in these experiments (Fig. 9).

Pretreatment of HUVEC with the potent phospholipase inhibitor $p$-bromophenacyl bromide (pBPB; $25 \mu \mathrm{M}$ for 15 min) (47) completely prevented enhanced PMN adhesion to $\mathrm{H}_{2} \mathrm{O}_{2}$-treated monolayers, reducing the adherence to the level seen in monolayers treated with control buffer rather than $\mathrm{H}_{2} \mathrm{O}_{2}$. PMN adhesion induced by thrombin, but not adhesion stimulated by $N$-formyl-methionyl-leucyl-phenylalanine (fMLP), was blocked by pBPB in parallel incubations. In two experiments PAF synthesis by HUVEC stimulated with $\mathrm{H}_{2} \mathrm{O}_{2}$ ( 5 or $10 \mathrm{mM}$ ), thrombin, or IoA was inhibited by greater than $95 \%$ by pretreatment of the EC with pBPB $(25 \mu \mathrm{m})$ for $15 \mathrm{~min}$. In two experiments to determine if RNA or protein synthesis was required for $\mathrm{H}_{2} \mathrm{O}_{2}$-induced $\mathrm{PMN}$ adhesion, pretreatment of HUVEC with cycloheximide ( 20 or $35 \mu \mathrm{M}$ for 1 or $4 \mathrm{~h}$ ) (48) or actinomycin $\mathrm{D}(5 \mu \mathrm{g} / \mathrm{ml}$ for $4 \mathrm{~h})(49)$ caused no decrease in neutrophil adherence to EC monolayers treated with 5 or 10 $\mathrm{mM} \mathrm{H} \mathrm{H}_{2} \mathrm{O}_{2}$. Inclusion of monensin $(1 \mu \mathrm{M})(48)$ during the 20-min preincubation period of HUVEC with $10 \mathrm{mM} \mathrm{H}_{2} \mathrm{O}_{2}$ did not reduce PMN adhesion to the monolayers in two experiments, suggesting that redistribution of preformed pro-

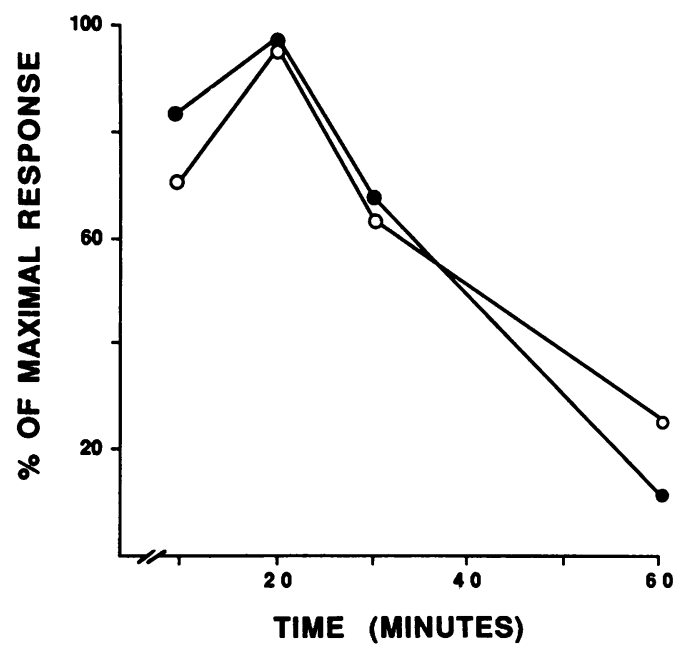

Figure 9. Endothelial cell-dependent PMN adhesion and PAF synthesis are temporally-associated events in $\mathrm{H}_{2} \mathrm{O}_{2}$-stimulated EC. HUVEC were grown in individual $35-\mathrm{mm}$ culture dishes, and incubated with $10 \mathrm{mM} \mathrm{H}_{2} \mathrm{O}_{2}$ for the indicated times. $\left[{ }^{3} \mathrm{H}\right.$-acetyl $] \mathrm{PAF}$ accumulation was determined as in Methods and PMN adhesion was measured as in Methods and Fig. 8. The figure indicates the mean data from three experiments for each measurement; in two experiments [ ${ }^{3} \mathrm{H}$-acetyl]PAF accumulation and PMN adhesion were measured in parallel in replicates from the same EC culture. 
teins was not involved (50). Furthermore, polyclonal antisera to human vWF and FN did not block PMN adhesion to $\mathrm{H}_{2} \mathrm{O}_{2}$-treated EC $(n=2)$. These results suggest that rapid expression of these adhesive glycoproteins on the EC surface (51), or alteration by $\mathrm{H}_{2} \mathrm{O}_{2}$ of vWF or FN that was constitutively associated with the EC plasma membrane or pericellular matrix (52), was not the mechanism of enhanced PMN adhesion. In an additional experiment we pretreated PMNs with buffer, $10^{-8} \mathrm{M}$ PAF, or $10^{-8} \mathrm{M}$ lyso-PAF (which is biologically inactive [24]) for $5 \mathrm{~min}$ at $37^{\circ} \mathrm{C}$, added them to $\mathrm{EC}$ monolayers that had been pretreated with $5 \mathrm{mM} \mathrm{H}_{2} \mathrm{O}_{2}$ for $20 \mathrm{~min}$, and then measured adherence after a 5-min incubation. Pretreatment with PAF reduced $\mathrm{PMN}$ adhesion to $\mathrm{H}_{2} \mathrm{O}_{2}$-activated monolayers by $65 \%$, compared to $13 \%$ with lyso-PAF. Adherence of PMN induced by exogenous fMLP was not substantially reduced by either PAF or lyso-PAF ( $88 \%$ of the value for buffer-pretreated $\mathrm{PMN}$ in each case). These data are consistent with specific desensitization of $\mathrm{PMN}$ adhesion to $\mathrm{H}_{2} \mathrm{O}_{2}$-treated endothelium by pretreatment with $\operatorname{PAF}(40,41)$.

\section{Discussion}

In this report we present evidence that BPAEC and HUVEC in primary culture synthesize and accumulate PAF when they are stimulated with hydrogen peroxide. Accumulation of PAF induced by $\mathrm{H}_{2} \mathrm{O}_{2}$ is concentration- and time-dependent, is associated with a calcium flux across the plasma membrane, and is temporally dissociated from lytic cell injury. $\mathrm{H}_{2} \mathrm{O}_{2}$ also induces rapid endothelial cell-dependent adherence of neutrophils that is temporally coupled with PAF accumulation in human endothelium. These observations document that $\mathrm{H}_{2} \mathrm{O}_{2}$ can directly activate EC and suggest a new mechanism by which oxidants may initiate or amplify inflammatory vascular injury. Although the concentrations of exogenously delivered reagent $\mathrm{H}_{2} \mathrm{O}_{2}$ required to induce these effects were high, and it is unknown if such concentrations are achieved in inflammed tissue in vivo, neutrophils generate and release sufficient $\mathrm{H}_{2} \mathrm{O}_{2}$ to cause high local concentrations $(1,12,53)^{2}$ and high local concentrations of endogenously generated oxidants may occur under hyperoxic conditions (3). Furthermore, the experiments that we have described may indicate a paradigm for responses of EC that are perturbed by oxidants, regardless of whether or not the concentrations of $\mathrm{H}_{2} \mathrm{O}_{2}$ that we utilized are achieved in vivo.

It has been documented previously that active oxygen species, including $\mathrm{H}_{2} \mathrm{O}_{2}$, can cause cytotoxic injury to EC (1-14). $\mathrm{H}_{2} \mathrm{O}_{2}$ causes lysis of cultured endothelium $(4-11,56)$ and, in concert with proteases generated by inflammatory cells (57), may cause desquamation of EC from the subcellular matrix. Similar alterations in vivo would result in wholesale destruction of the luminal surface. However, evidence for widespread EC lysis and extensive denudation of the intima is not commonly found in the acute phases of conditions that are thought to involve oxidant-induced vascular injury, even though there is concurrent evidence for abnormal vascular function (such as increased permeability, altered vasoreactivity, or thrombosis)

2. Recently Nathan (54) has reported that PMN release "massive" quantities of $\mathrm{H}_{2} \mathrm{O}_{2}$ under certain conditions. Also, Bozeman et al. (55) estimated that millimolar concentrations of $\mathrm{H}_{2} \mathrm{O}_{2}$ may be achieved in inflammatory lesions containing neutrophils.
$(2,3,58,59)$. This suggests that the $\mathrm{EC}$ are intact, but that their basal functions have been perturbed. Furthermore, some models of oxidant-induced vascular injury indicate that there are reversible alterations in endothelial permeability that do not involve cell death (14). The biochemical mechanisms involved in oxidant-induced, nonlytic EC alterations are largely unknown (1). Our studies demonstrate that $\mathrm{H}_{2} \mathrm{O}_{2}$ induces PAF synthesis by human and bovine endothelium, a biochemical response that may contribute to such functional alterations.

PAF synthesis requires specific enzymatic activities (60). Although more than one pathway for PAF synthesis exists in mammalian cells, in endothelium it occurs by the sequential phospholipase $\mathrm{A}_{2}$-catalyzed hydrolysis of 1-0-alkyl-2-acyl-snglycero-3-phosphocholine to form 1-0-alkyl-sn-glycero-3phosphocholine ("lyso-PAF") followed by acetylation of this molecule to form PAF (1-0-alkyl-2-acetyl-sn-glycero-3-phosphocholine); the latter step is catalyzed by an intracellular acetyl transferase (60-62). The mechanism by which $\mathrm{H}_{2} \mathrm{O}_{2}$ "switches on" this enzymatic pathway may involve a $\mathrm{Ca}^{2+}$ flux across the EC plasma membrane since $\mathrm{H}_{2} \mathrm{O}_{2}$ caused increased permeability of the $\mathrm{EC}$ for $\mathrm{Ca}^{2+}$ and accumulation of radiolabeled $\mathrm{Ca}^{2+}$ in the cells (Fig. 3). Furthermore, a sustained increase in intracellular $\mathrm{Ca}^{2+}$ induced by receptor-mediated and receptor-independent perturbation of EC results in PAF synthesis (Whatley et al., manuscript submitted for publication). Shasby et al. previously reported that a xanthine/xanthine oxidase system caused increased permeability of porcine EC for ${ }^{45} \mathrm{Ca}^{2+}(63)$; preliminary experiments indicate that linoleate peroxide causes ${ }^{45} \mathrm{Ca}^{2+}$ release from preloaded, cultured EC and that $\mathrm{H}_{2} \mathrm{O}_{2}$ induces the generation of linoleate peroxide by these cells (64). Lipid peroxides, including linoleate peroxide, may act as $\mathrm{Ca}^{2+}$ ionophores (65). Thus $\mathrm{H}_{2} \mathrm{O}_{2}$ may have induced increased calcium permeability and PAF synthesis by the EC by causing the generation of lipid peroxides. Increased intracellular $\mathrm{Ca}^{2+}$ also initiates the synthesis of $\mathrm{PGI}_{2}$ by endothelium (66). Consistent with this, we found that $\mathrm{H}_{2} \mathrm{O}_{2}$ induced the coordinate accumulation of PAF and 6-keto-PGF ${ }_{1 a}$ (see Results) confirming earlier observations that $\mathrm{H}_{2} \mathrm{O}_{2}$ can stimulate $\mathrm{PGI}_{2}$ synthesis by $\mathrm{EC}(7,43)$ as well as our previous finding that $\mathrm{PAF}$ and $\mathrm{PGI}_{2}$ synthesis are initiated in concert in activated endothelium $(22,23,33)$. These findings suggest that $\mathrm{H}_{2} \mathrm{O}_{2}$ induces $\mathrm{Ca}^{2+}$ flux, activation of phospholipase $\mathrm{A}_{2}$ (thought to be a $\mathrm{Ca}^{2+}$-dependent enzyme), and the hydrolysis of one or more membrane phospholipid precursors in endothelium, yielding free arachidonate and lyso-PAF for subsequent conversion to $\mathrm{PGI}_{2}$ and $\mathrm{PAF}$, respectively (Whatley et al., manuscript submitted for publication).

As in our experiments, previous studies with cultured EC from several sources demonstrate that enzymatic synthesis of biologically active molecules can be stimulated by $\mathrm{H}_{2} \mathrm{O}_{2}$ in the absence of lytic injury $(7,43)$. Additional biologic and biochemical alterations in ' $\mathrm{EC}$ induced by $\mathrm{H}_{2} \mathrm{O}_{2}$ or other active $\mathrm{O}_{2}$ species at time points before cell lysis, or in cells treated with sublytic concentrations of $\mathrm{H}_{2} \mathrm{O}_{2}$, include potassium efflux and the release of cytoplasmic purines (7), reorganization of actin filaments (63), and reduction in cellular ATP levels (11).

We found that the concentration-response relationship for $\mathrm{H}_{2} \mathrm{O}_{2}$-induced PAF synthesis was quite narrow (Fig. 1), and that concentrations of $\mathrm{H}_{2} \mathrm{O}_{2}$ greater than $10 \mathrm{mM}$ decreased or abolished PAF accumulation in both BPAEC and HUVEC. These results suggest that high concentrations of $\mathrm{H}_{2} \mathrm{O}_{2}$ may inactivate one or more of the enzymes involved in PAF syn- 
thesis. We also found that pretreatment of HUVEC with submaximal concentrations of $\mathrm{H}_{2} \mathrm{O}_{2}$ reduced PAF accumulation when the monolayers were subsequently stimulated with thrombin (see Results). A variable effect of oxidants on eicosanoid synthesis, depending on the concentration of the oxidant, has also been reported $(7,10,43)$. Whorton et al. (10) observed that pretreatment of cultured porcine endothelium with concentrations of $\mathrm{H}_{2} \mathrm{O}_{2}(0.01-0.1 \mathrm{mM})$ that did not induce $\mathrm{PGI}_{2}$ synthesis, or coincident cell lysis, impaired $\mathrm{PGI}_{2}$ synthesis when the EC were subsequently treated with exogenous arachidonate or ionophore A23187, and that cyclooxygenase, but not $\mathrm{PGI}_{2}$ synthase, was inhibited under these conditions. Taylor et al. found that t-butyl hydroperoxide stimulated the production of $\mathrm{PGI}_{2}$ at low concentrations and inhibited it at high concentrations; the inhibition at high concentrations was reversed by addition of an oxygen radical scavenger (67). These reports, and our observations on PAF synthesis, are consistent with evidence that $\mathrm{H}_{2} \mathrm{O}_{2}$ and other oxidants can cause rapid, selective damage to enzymes and other intracellular proteins, and intracellular proteolysis of the altered molecules (68). Thus the effect of $\mathrm{H}_{2} \mathrm{O}_{2}$ on the production of lipid autacoids by $\mathrm{EC}$ may depend heavily on variables that include the concentrations of the oxidant (Figs. 1 and 7) and endogenous antioxidants $(8,12)$, time (Fig. 7$)$, and the presence or absence of additional agonists.

We found that $\mathrm{H}_{2} \mathrm{O}_{2}$ induced neutrophil adherence that was dependent on the endothelium. Endothelial cell-dependent PMN adherence is a novel biologic response to $\mathrm{H}_{2} \mathrm{O}_{2}$ that has not been previously reported, although PMN adhesion to the intima of oxidant-injured vessels and to EC cultured under hyperoxic conditions has been described $(69,70)$. EC-dependent PMN adherence has been observed when cultured endothelium is stimulated by a variety of naturally occurring inflammatory mediators including thrombin $(20,40,42)$, sulfidopeptide leukotrienes $(41)$, and cytokines $(49,71)$, and may contribute to the accumulation of PMN in vessels in certain pathologic conditions such as the adult respiratory distress syndrome (72). In our experiments, $\mathrm{H}_{2} \mathrm{O}_{2}$-induced, EC-dependent neutrophil adherence was very rapid, with an onset within minutes and a peak that usually occurred within $20 \mathrm{~min}$ (Fig. 9), and was not dependent on de novo protein synthesis by the EC. These features clearly differentiate it from EC-dependent PMN adhesion stimulated by the cytokines tumor necrosis factor and interleukin 1, and by endotoxin, which require $\sim 1 \mathrm{~h}$ for onset, $4-6 \mathrm{~h}$ for the maximal effect, and the synthesis of new protein(s) $(49,71)$. The rapidity with which $\mathrm{H}_{2} \mathrm{O}_{2}$ stimulates EC-dependent $\mathrm{PMN}$ adhesion is similar to the onset induced by thrombin, $\mathrm{LTC}_{4}$ and $\mathrm{LTD}_{4}(20,40-42)$.

There are several possible molecular events that may contribute to $\mathrm{H}_{2} \mathrm{O}_{2}$-induced EC-dependent adhesion. $\mathrm{H}_{2} \mathrm{O}_{2}$ may stimulate the translocation of a preformed adhesive protein from an intracellular compartment to the EC plasma membrane. The lack of an effect of 4-h preincubation of the EC with cycloheximide, or of treatment of EC with monensin (50), argue against this possibility, and polyclonal antibodies against two adhesive glycoproteins (vWF and fibronectin) that are associated with EC (51) did not inhibit PMN adhesion. A second possibility is that $\mathrm{H}_{2} \mathrm{O}_{2}$ induces a conformational change, or a change in the primary structure, of a constitutive surface or pericellular protein (68) causing it to become adhesive (52). However, treatment of matrices of relevant proteins or subendothelial matrices with $\mathrm{H}_{2} \mathrm{O}_{2}$ under the conditions of these experiments did not induce enhanced PMN adherence. A third possibility is that PAF that is synthesized by $\mathrm{H}_{2} \mathrm{O}_{2}$ stimulated EC mediates the adhesive interaction. We have previously reported evidence that PAF that is endogenously synthesized by activated EC, and that remains cell-associated, may cause PMN adhesion $(23,40-42,61)$. In the current experiments the time courses for $\mathrm{H}_{2} \mathrm{O}_{2}$-stimulated PAF accumulation and for PMN adhesion to the EC were strikingly similar (Fig. 9) as were the concentration-response relationships. $\mathrm{H}_{2} \mathrm{O}_{2}$-induced $\mathrm{PMN}$ adhesion was inhibited by the potent (47, 73) but nonspecific (73) phospholipase inhibitor pBPB, which also inhibited PAF synthesis. Furthermore, there was reduced binding of PMN that were specifically "desensitized" by pretreatment with submaximal concentrations of PAF to $\mathrm{H}_{2} \mathrm{O}_{2}$ treated EC. These observations suggest that a portion of the PAF synthesized by EC in response to $\mathrm{H}_{2} \mathrm{O}_{2}$ is located in the plasma membrane or is otherwise available for interaction with adjacent neutrophils. In addition, competitive PAF receptor antagonists diminish PMN adherence to $\mathrm{H}_{2} \mathrm{O}_{2}$-treated HUVEC (Zimmerman et al., manuscript in preparation).

PAF synthesis, EC-dependent PMN adhesion, and $\mathrm{PGI}_{2}$ production are rapid responses of endothelial cells that are activated by specific agonists (23). This report demonstrates that $\mathrm{H}_{2} \mathrm{O}_{2}$, like receptor-mediated agonists, can stimulate the first two of these, adding them to the repertoire of biochemical and biologic responses of vessels that are perturbed by active $\mathrm{O}_{2}$ metabolites (1). Because of the vasoactive and prothrombotic effects of PAF $(24-33,44)$, and the ability of adherent PMNs to cause endothelial damage $(1,4-6,56,57)$, activation of $\mathrm{EC}$ by $\mathrm{H}_{2} \mathrm{O}_{2}$ has the potential to mediate pathologic events in oxidant-induced vascular injury states before the onset of lytic destruction of the intima, or in segments of the intima that are not destined for necrosis because they have been perturbed by sublytic concentrations of the toxic $\mathrm{O}_{2}$ species. Since PMN release $\mathrm{H}_{2} \mathrm{O}_{2}$ into the fluid phase $(1,55)$, the activation of $\mathrm{EC}$ by $\mathrm{H}_{2} \mathrm{O}_{2}$, resulting in PAF synthesis, provides the basis for a reciprocal amplification loop between the two cells. We have observed that PMN that become adherent to activated EC develop morphologic evidence indicating that the leukocytes in turn become activated (membrane spreading and polarization), suggesting that signals received by the PMN from the EC can close such an amplification loop $(40-42,61)$. It is also possible that such a reciprocal interaction may occur in physiologic as well as pathologic inflammatory events, since the EC generate biologically active molecules (74), such as $\mathrm{PGI}_{2}$, that may modulate $\mathrm{PMN}$ responses $(45,74,75)$, and create a regulated, homeostatic interaction.

\section{Acknowledgments}

The authors are grateful to Donelle Benson and Tony Seeger for excellent technical assistance; Leona Archuleta, Doris Land, and Linda Jara for careful preparation of the manuscript and figures; and the staff of the Labor and Delivery Service of the LDS Hospital for invaluable help in collecting umbilical cord specimens.

This work was supported by the Nora Eccles Treadwell Foundation, grants from the National Institutes of Health (RO1 HL35828, RO1 HL34127, and F32 HL07529) and grants-in-aid from the American Heart Association (No. 84-975, No. 871147). Guy A. Zimmerman and Stephen M. Prescott are recipients of Established Investigator Awards (Nos. 85-204 and 87-0225) from the American Heart Association. 


\section{References}

1. Henson, P. M., and R. B. Johnston. 1987. Tissue injury in inflammation. Oxidants, proteinases, and cationic proteins. J. Clin. Invest. 79:669-674.

2. Frank, L. 1985. Oxidant injury to pulmonary endothelium. In The Pulmonary Circulation and Acute Lung Injury. S. I. Said, editor. Futura Publishing Co., Mt. Kisco, NY. 283-305.

3. Crapo, J. D. 1986. Morphologic changes in pulmonary oxygen toxicity. Annu. Rev. Physiol. 48:721-731.

4. Sacks, T., C. F. Moldow, P. R. Craddock; T. K. Bowers, and H. S. Jacob. 1978. Oxygen radicals mediate endothelial cell damage by complement-stimulated granulocytes. J. Clin. Invest. 61:1161-1167.

5. Weiss, S. J., J. Young, A. F. LoBuglio, A. Slivka, and N. F. Nimeh. 1981. Role of hydrogen peroxide in neutrophil-mediated destruction of cultured endothelial cells. J. Clin. Invest. 68:714-721.

6. Suttorp, N., and L. M. Simon. 1982. Lung cell oxidant injury. Enhancement of polymorphonuclear leukocute-mediated cytotoxicity in lung cells exposed to sustained in vitro hyperoxia. J. Clin. Invest. 70:342-350.

7. Ager, A., and J. L. Gordon. 1984. Differential effects of hydrogen peroxide on indices of endothelial cell function. J. Exp. Med. 159:592-603.

8. Harlan, J. M., J. D. Levine, K. S. Callahan, B. R. Schwartz, and L. A. Harker. 1984. Glutathione redox cycle protects cultured endothelial cells against lysis by extracellularly generated hydrogen peroxide. J. Clin. Invest. 73:706-713.

9. Martin, W. J. 1984. Neutrophils kill pulmonary endothelial cells by a hydrogen-peroxide-dependent pathway. An in vitro model of neutrophil-mediated lung injury. Am. Rev. Respir. Dis. 130:209-213.

10. Whorton, A. R., M. E. Montgomery, and R. S. Kent. 1985. Effect of hydrogen peroxide on prostaglandin production and cellular integrity in cultured porcine aortic endothelial cells. J. Clin. Invest. 76:295-302.

11. Spragg, R. G., D. B. Hinshaw, P. A. Hyslop, I. U. Schraufstätter, and C. G. Cochrane. 1985. Alterations in adenosine triphosphate and energy charge in cultured endothelial cells and

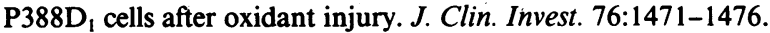

12. Dobrina, A., and P. Patricia. 1986. Neutrophil-endothelial cell interaction. Evidence for and mechanisms of the self-protection of bovine microvascular endothelial cells from hydrogen peroxide-induced oxidative stress. J. Clin. Invest. 78:462-471.

13. Starkebaum, G., and J. M. Harlan. 1986. Endothelial cell injury due to copper-catalyzed hydrogen peroxide generation from homocysteine. J. Clin. Invest. 77:1370-1376.

14. Toth, K. M., D. P. Clifford, E. M. Berger, C. W. White, and J. E. Repine. 1984. Intact human erythrocytes prevent hydrogen peroxidemediated damage to isolated perfused rat lungs and cultured bovine pulmonary artery endothelial cells. J. Clin. Invest. 74:292-295.

15. Till, G. O., K. J. Johnson, R. Kunkel, and P. A. Ward. 1982. Intravascular activation of complement and acute lung injury. Dependency on neutrophils and toxic oxygen metabolites. J. Clin. Invest. 69:1126-1135.

16. Tate, R. M., K. M. VanBenthuysen, D. M. Shasby, I. F. McMurtry, and J. E. Repine. 1982. Oxygen-radical-mediated permeability edema and vasoconstriction in isolated perfused rabbit lungs. Am. Rev. Respir. Dis. 126:802-806.

17. Burghuber, O., M. M. Matthias, I. F. McMurtry, J. T. Reeves, and N. F. Voelkel. 1984. Lung edema due to hydrogen peroxide is independent of cyclooxygenase products. J. Appl. Physiol. 56:900905.

18. Weisfeldt, M. L. 1987. Reperfusion and reperfusion injury. Clin. Res. 35:13-20.

19. Jaffe, E. A. 1985. Physiologic functions of normal endothelial cells. Ann. N.Y. Acad. Sci. 454:279-291.

20. Prescott, S. M., G. A. Zimmerman, and T. M. McIntyre. 1984. Human endothelial cells in culture produce platelet-activating factor (1-alkyl-2-acetyl-sn-glycero-3-phosphocholine) when stimulated with thrombin. Proc. Natl. Acad. Sci. USA. 81:3534-3538.

21. Camussi, G., M. Aglietta, F. Malavasi, C. Tetta, W. Piacibello, F. Sanavio, and F. Bussolino. 1983. The release of platelet-activating factor from human endothelial cells in culture. J. Immunol. 131:2397-2403.

22. McIntyre, T. M., G. A. Zimmerman, K. Satoh, and S. M. Prescott. 1985. Cultured endothelial cells synthesize both platelet-activating factor and prostacyclin in response to histamine, bradykinin, and adenosine triphosphate. J. Clin. Invest. 76:271-280.

23. Zimmerman, G. A., R. E. Whatley, T. M. McIntyre, and S. M. Prescott. 1987. Production of platelet-activating factor, a biologically active lipid, by vascular endothelial cells. Am. Rev. Respir. Dis. 136:204-207.

24. Hanahan, D. J. 1986. Platelet-activating factor: A biologically active phosphoglyceride. Annu. Rev. Biochem. 55:483-509.

25. Camussi, G., and J. R. Brentjens. 1987. The role of platelet activating factor in inflammation. In Platelet-activating Factor and Related Lipid Mediators. F. Snyder, editor. Plenum Publishing Corp., New York and London. 299-323.

26. Voelkel, N. F., S. W. Chang, T. J. McDonnell, J. Y. Westcott, and J. Haynes. 1987. Role of membrane lipids in control of normal vascular tone. Am. Rev. Respir. Dis. 136:214-217.

27. Lewis, J. C., J. T. O'Flaherty, C. E. McCall, R. L. Wykle, and M. G. Bond. 1983. Platelet activating factor effects on pulmonary ultrastructure in rabbits. Exp. Mol. Pathol. 38:100-108.

28. Chang, S-W., F. O. Fedderson, P. M. Henson, and N. F. Voelkel. 1987. Platelet-activating factor mediates hemodynamic changes and lung injury in endotoxin-treated rats. J. Clin. Invest. 79:14981509.

29. Heffner, J. E., S. A. Shoemaker, E. M. Canham, M. Patel, I. F. McMurtry, H. G. Morris, and J. E. Repine. 1983. Acetyl glyceryl ether phosphorylcholine-stimulated human platelets cause pulmonary hypertension and edema in isolated rabbit lungs: role of thromboxane $\mathrm{A}_{2}$. J. Clin. Invest. 71:351-357.

30. Hamasaki, Y., M. Mojarad, T. Saga, H-H. Tai, and S. I. Said. 1984. Platelet-activating factor raises airway and vascular pressures and induces edema in lungs perfused with platelet-free solution. $\mathrm{Am}$. Rev. Respir. Dis. 129:742-746.

3i. Kenzora, J. L., J. E. Pérez, S. R. Bergmann, and L. G. Lange. 1984. Effects of acetyl glyceryl ether phosphorylcholine (platelet-activating factor) on ventricular preload, afterload, and contractility in dogs. J. Clin. Invest. 74:1193-1203.

32. Burhop, K. E., H. Van Der Zee, R. Bizios, J. E. Kaplan, and A. B. Malik. 1986. Pulmonary vascular response to platelet-activating factor in awake sheep and the role of cyclooxygenase metabolites. Am. Rev. Respir. Dis. 134:548-554.

33. Whatley, R. E., G. A. Zimmerman, T. M. McIntyre, S. M. Prescott. 1988. Endothelium from diverse vascular sources synthesizes platelet-activating factor when stimulated by specific agonists. Arteriosclerosis. 8:321-331.

34. Mueller, H. W., J. T. O'Flaherty, and R. L. Wykle. 1984. The molecular species distribution of platelet-activating factor synthesized by rabbit and human neutrophils. J. Biol. Chem. 259:14554-14559.

35. Ramesha, C. S., and W. C. Pickett. 1986. Platelet-activating factor and leukotriene biosynthesis is inhibited in polymorphonuclear leukocytes depleted of arachidonic acid. J. Biol. Chem. 259:75927595.

36. Sisson, J. H., S. M. Prescott, T. M. McIntyre, and G. A. Zimmerman. 1987. Production of platelet-activating factor in stimulated human polymorphonuclear leukocytes. Correlation of synthesis with release, functional events, and leukotriene $\mathrm{B}_{4}$ metabolism. J. Immunol. 138:3918-3926.

37. Bligh, E. G., and W. J. Dyer. 1959. A rapid method of total lipid extraction and purification. Can. J. Biochem. Physiol. 37:911-917.

38. Stafforini, D. M., S. M. Prescott, and T. M. McIntyre. 1987. 
Human plasma platelet-activating factor acetylhydrolase. Purification and properties. J. Biol. Chem. 262:4223-4230.

39. Patterson, M. K. 1979. Measurement of growth and viability of cells in culture. In Cell Culture. Methods Enzymol. 58:141-152.

40. Zimmerman, G. A., T. M. McIntyre, and S. M. Prescott. 1985. Thrombin stimulates the adherence of neutrophils to human endothelial cells in vitro. J. Clin. Invest. 76:2235-2246.

41. McIntyre, T. M., G. A. Zimmerman, and S. M. Prescott. 1986. Leukotrienes $\mathrm{C}_{4}$ and $\mathrm{D}_{4}$ stimulate human endothelial cells to synthesize platelet-activating factor and bind neutrophils. Proc. Natl. Acad. Sci. USA. 83:2204-2208.

42. Zimmerman, G. A., T. M. McIntyre, and S. M. Prescott. 1986. Thrombin stimulates neutrophil adherence by an endothelial cell-dependent mechanism: Characterization of the response and relationship to platelet-activating factor synthesis. Ann. N.Y. Acad. Sci. 405:349368.

43. Harlan, J. M., and K. S. Callahan. 1984. Role of hydrogen peroxide in the neutrophil-mediated release of prostacyclin from cultured endothelial cells. J. Clin. Invest. 74:442-448.

44. Camussi, G., I. Pawlowski, F. Bussolino, P. B. Caldwell, J. Brentjens, and G. Andres. 1983. Release of platelet-activating factor in rabbits with antibody-mediated injury to the lung: The role of leukocytes and of pulmonary endothelial cells. J. Immunol. 131:1802-1807.

45. Zimmerman, G. A., G. A. Wiseman, and H. R. Hill. 1985. Human endothelial cells modulate granulocyte adherence and chemotaxis. J. Immunol. 134:1866-1874.

46. Berger, E. M., C. J. Beehler, R. N. Harada, and J. E. Repine. 1987. Phagocytic cells as scavengers of hydrogen peroxide $\left(\mathrm{H}_{2} \mathrm{O}_{2}\right)$. Clin. Res. 35:170A. (Abstr.)

47. Parthasarathy, S., U. P. Steinbrecher, J. Barnett, J. L. Witzum, and D. Steinberg. 1985. Essential role of phospholipase $A_{2}$ activity in endothelial cell-induced modification of low density lipoprotein. Proc. Natl. Acad. Sci. USA. 82:3000-3004.

48. Dejana, E., S. Colella, L. A. Languino, G. Balconi, G. C. Corbascio, and P. C. Marchisio. 1987. Fibrinogen induces adhesion, spreading, and microfilament organization of human endothelial cells in vitro. J. Cell Biol. 104:1403-1411.

49. Bevilacqua, M. P., J. S. Putzer, M. E. Wheeler, R. S. Cotran, and M. A. Gimbrone. 1985. Interleukin-1 acts on cultured human vascular endothelium to increase the adhesion of polymorphonuclear leukocytes, monocytes, and related leukocyte cell lines. J. Clin. Invest. 76:2003-2011.

50. Uchida, N., H. Smilowitz, and M. L. Tanzer. 1979. Monovalent ionophores inhibit secretion of procollagen and fibronectin from cultured human fibroblasts. Proc. Natl. Acad. Sci. USA. 76:18681872.

51. Reinders, J. H., P. G. de Groot, J. Dawes, N. R. Hunter, H. A. A. van Heugten, J. Zandbergen, M. D. Gonsalves, and J. A. van Mourik. 1985. Comparison of secretion and subcellular localization of von Willebrand protein with that of thrombospondin and fibronectin in cultured human vascular endothelial cells. Biochim. Biophys. Acta. 844:306-313.

52. Vercelloti, G. M., J. McCarthy, L. T. Furcht, H. S. Jacob, and C. T. Moldow. 1983. Inflamed fibronectin: an altered fibronectin enhances neutrophil adhesion. Blood. 62:1063-1069.

53. Test, S. T., and S. J. Weiss. 1984. Quantitative and temporal characterization of the extracellular $\mathrm{H}_{2} \mathrm{O}_{2}$ pool generated by human neutrophils. J. Biol. Chem. 259:399-405.

54. Nathan, C. F. 1987. Neutrophil activation on biological surfaces. Massive secretion of hydrogen peroxide in response to products of macrophages and lymphocytes. J. Clin. Invest. 80:1550-1560.

55. Bozeman, P. M., J. R. Hoidal, and V. L. Shepherd. 1988. Oxidant-mediated inhibition of ligand uptake by the macrophage mannose receptor. J. Biol. Chem. 263:1240-1247.

56. Smedley, L. A., M. G. Tonnensen, R. A. Sandhaus, C. Haslett, L. A. Guthrie, R. B. Johnston, P. M. Henson, and G. S. Worthen. 1986. Neutrophil-mediated injury to endothelial cells. Enhancement by endotoxin and essential role of neutrophil elastase. J. Clin. Invest. 77:1233-1243.
57. Harlan, J. M., P. D. Killen, L. A. Harker, G. E. Striker, and D. G. Wright. 1981. Neutrophil-mediated endothelial injury in vitro. J. Clin. Invest. 68:1394-1403.

58. Bachofen, M., and E. R. Weibel. 1977. Alterations in the gas exchange apparatus in adult respiratory distress syndrome associated with septicemia. Am. Rev. Respir. Dis. 116:589-615.

59. Van Benthuysen, K. M., I. F. McMurtry, and L. D. Horwitz. 1987. Reperfusion after acute coronary occlusion in dogs impairs endothelium-derived relaxation to acetylcholine and augments contractile reactivity in vitro. J. Clin. Invest. 79:265-274.

60. Snyder, F. 1987. The significance of dual pathways for the biosynthesis of platelet activating factor: 1-alkyl-2-lyso-sn-glycero-3phosphate as a branchpoint. In New Horizons in Platelet-activating Factor Research. C. M. Winslow and M. L. Lee, editors. John Wiley \& Sons, Ltd., London. 13-25.

61. Prescott, S. M., G. A. Zimmerman, and T. M. McIntyre. 1987. The production of platelet-activating factor by cultured human endothelial cells: Regulation and function. In Platelet Activating Factor. F. Snyder, editor. Plenum Publishing Corp., New York. 323-339.

62. Bussolino F., F. Brevario, M. Aglietta, F. Sanavio, A. Bosia, and E. Dejana. 1987. Studies on the mechanism of interleukin 1 stimulation of platelet-activating factor synthesis in human endothelial cells in culture. Biochim. Biophys. Acta. 927:43-54.

63. Shasby, D. M., S. E. Lind, S. S. Shasby, J. C. Goldsmith, and G. W. Hunninghake. 1985. Reversible oxidant-induced increases in albumin transfer across cultured endothelium: alterations in cell shape and calcium homeostasis. Blood. 65:605-614.

64. Shasby, D. M. 1987. Lipid peroxidation in $\mathrm{Ca}^{2+}$ dependent, reversible oxidant injury to endothelium. Clin. Res. 35:539A. (Abstr.)

65. Serhan, C., P. Anderson, E. Goodman, P. Dunham, and G. Weissmann. 1981. Phosphatidate and oxidized fatty acids are calcium ionophores. Studies employing arsenazo III in liposomes. J. Biol. Chem. 256:2736-2741.

66. Jaffe, E. A., J. Grulich, B. B. Weksler, G. Hampel, and K. Watanabe. 1987. Correlation between thrombin-induced prostacyclin production and inositol triphosphate and cytosolic free calcium levels in cultured human endothelial cells. J. Biol. Chem. 262:8557-8565.

67. Taylor, L., M. J. Menconi, and P. Polgar. 1983. The participation of hydrogen peroxides and oxygen radicals in the control of prostaglandin synthesis. J. Biol. Chem. 258:6855-6857.

68. Davies, K. J. A., and A. L. Goldberg. 1987. Oxygen radicals stimulate intracellular proteolysis and lipid peroxidation by independent mechanisms in erythrocytes. J. Biol. Chem. 262:8220-8226.

69. Del Maestro, R., H. H. Thaw, J. Björk, M. Planker, and K. E. Arfors. 1980. Free radicals as mediators of tissue injury. Acta Physiol. Scand. (Suppl.). 492:153-168.

70. Bowman, C. M., E. N. Butler, and J. E. Repine. 1983. Hyperoxia damages cultured endothelial cells causing increased neutrophil adherence. Am. Rev. Respir. Dis. 128:469-472.

71. Pohlman, T. H., K. A. Stanness, P. G. Beatty, H. D. Ochs, and J. M. Harlan. 1986. An endothelial cell surface factor(s) induced in vitro by lipopolysaccharide, interleukin-1, and tumor necrosis factor ${ }_{\alpha}$ increases neutrophil adherence by a CDw18-dependent mechanism. $J$. Immunol. 136:4548-4553.

72. Zimmerman, G. A., A. D. Renzetti, and H. R. Hill. 1984. Granulocyte adherence in pulmonary and systemic arterial blood samples from patients with adult respiratory distress syndrome. Am. Rev. Respir. Dis. 129:798-804.

73. Hofmann, S. L., S. M. Prescott, and P. W. Majerus. 1982. The effects of mepacrine and p-bromophenacyl bromide on arachidonic acid release in human platelets. Arch. Biochem. Biophys. 215:237-244.

74. Zimmerman, G. A., and D. Klein-Knoeckel. 1986. Human endothelial cells inhibit granulocyte aggregation in vitro. J. Immunol. 136:3839-3847.

75. Rampart, M., and T. J. Williams. 1986. Polymorphonuclear leukocyte-dependent plasma leakage in the rabbit skin is enhanced or inhibited by prostacyclin, depending on the route of administration. Am. J. Pathol. 124:66-73. 